University of Nebraska - Lincoln

DigitalCommons@University of Nebraska - Lincoln

Publications, Agencies and Staff of the U.S.

Department of Commerce

U.S. Department of Commerce

2010

Recent changes in density, biomass, recruitment, size structure, and nutritional state of Dreissena populations in southern Lake Michigan

\author{
Thomas F. Nalepa \\ National Oceanic and Atmospheric Administration, thomas.nalepa@noaa.gov \\ David L. Fanslow \\ National Oceanic and Atmospheric Administration, David.Fanslow@noaa.gov \\ Steven A. Pothoven \\ National Oceanic and Atmospheric Administration, Steve.Pothoven@nall.gov
}

Follow this and additional works at: https://digitalcommons.unl.edu/usdeptcommercepub

Part of the Environmental Sciences Commons

\footnotetext{
Nalepa, Thomas F.; Fanslow, David L.; and Pothoven, Steven A., "Recent changes in density, biomass, recruitment, size structure, and nutritional state of Dreissena populations in southern Lake Michigan" (2010). Publications, Agencies and Staff of the U.S. Department of Commerce. 404.

https://digitalcommons.unl.edu/usdeptcommercepub/404

This Article is brought to you for free and open access by the U.S. Department of Commerce at DigitalCommons@University of Nebraska - Lincoln. It has been accepted for inclusion in Publications, Agencies and Staff of the U.S. Department of Commerce by an authorized administrator of DigitalCommons@University of Nebraska - Lincoln.
} 


\title{
Recent changes in density, biomass, recruitment, size structure, and nutritional state of Dreissena populations in southern Lake Michigan
}

\author{
Thomas F. Nalepa ${ }^{\text {a,* }}$, David L. Fanslow ${ }^{\text {a }}$, Steven A. Pothoven ${ }^{\text {b }}$ \\ a Great Lakes Environmental Research Laboratory, NOAA, 4840 S. State St., Ann Arbor, MI 48108, USA \\ b Great Lakes Environmental Research Laboratory, NOAA, Lake Michigan Field Station, 1431 Beach St., Muskegon, MI 49441, USA
}

\section{A R T I C L E I N F O}

Article history:

Received 4 November 2009

Accepted 10 January 2010

Communicated by Gary Fahnenstiel

Index words:

Quagga mussels

Zebra mussels

Benthic community

\begin{abstract}
A B S T R A C T
Trends in density, biomass, population structure, and nutritional state of Dreissena polymorpha and Dreissena rostriformis bugensis were examined in southern Lake Michigan between the 1990s and 2008. Density and biomass of $D$. polymorpha increased to a peak in the early 2000s and then declined. In contrast, $D$. rostriformis bugensis was first found in the southern basin in 2001 and has continued to increase in density or biomass at all depths ever since. In 2008, maximum mean density of D. rostriformis bugensis occurred at 16-30 m $\left(19,000 / \mathrm{m}^{2}\right)$, but maximum biomass (AFDW) occurred at $31-50 \mathrm{~m}\left(43.9 \mathrm{~g} / \mathrm{m}^{2}\right)$. D. rostriformis bugensis has only recently (since 2005) began to increase at depths $>50 \mathrm{~m}$. When both species were present in 2004 at depths $<50 \mathrm{~m}$, a condition index $(\mathrm{CI})$ for D. rostriformis bugensis was $27 \%$ higher, and shell weight per shell length was $48 \%$ lower compared to D. polymorpha. For D. rostriformis bugensis, Cl decreased in 2008 compared to 2004 at $25 \mathrm{~m}$ and $45 \mathrm{~m}$, but biochemical content (lipid, glycogen) did not. Seasonal changes in both RNA/DNA ratio (growth) and ETS (metabolic activity) in D. rostriformis bugensis were unaffected by reproductive activity, and only ETS appeared to change seasonally relative to bottom temperatures. Spawning of $D$. rostriformis bugensis occurred in late summer at $25 \mathrm{~m}$, but occurred in spring at $45 \mathrm{~m}$. Veliger densities peaked in both spring and late summer at both depths. Future population expansion (biomass) is expected to be most rapid at depths $>50 \mathrm{~m}$.
\end{abstract}

Published by Elsevier B.V.

\section{Introduction}

In the late 1980s, two invading bivalve mollusks, Dreissena polymorpha (zebra mussel) and Dreissena rostriformis bugensis (quagga musssel), became established in the Great Lakes and have since spread into a wide range of habitats in all five lakes. $D$. polymorpha expanded rapidly and reached greatest abundances in shallow, nearshore regions and bays; $D$. rostriformis bugensis expanded more systematically but over time has become abundant in both nearshore and offshore regions (Mills et al., 1999; Patterson et al., 2005; Nalepa et al., 2009). The capacity of both species to filter large volumes of water, assimilate suspended material, and excrete nutrients has caused broad scale and fundamental changes in the cycling of energy and nutrients through the Great Lakes system (Nalepa and Fahnenstiel, 1995; Vanderploeg et al., 2002; Hecky et al., 2004).

For various reasons, less is known of the population dynamics, life habits, and nutritional state of $D$. rostriformis bugensis compared to $D$. polymorpha, particularly in deep, consistently cold regions. For one, with the exception of eastern Lake Erie, the spread of $D$. rostriformis

\footnotetext{
* Corresponding author. Tel.: +1 7347412285.

E-mail addresses: Thomas.Nalepa@noaa.gov (T.F. Nalepa), David.Fanslow@noaa.gov (D.L. Fanslow), Steve.Pothoven@nall.gov (S.A. Pothoven).
}

bugensis into offshore regions of the Great Lakes is generally recent (Watkins et al., 2007; Nalepa et al., 2009). In Europe, this species is confined to relatively shallow regions (Mills et al., 1996). Unique to the Great Lakes is the presence of two phenotypes of $D$. rostriformis bugensis, the hypolimnetic phenotype ("profunda") and the eplimnetic phenotype, which complicates our understanding of spatial distributions and life cycles. These phenotypes are genetically similar but have different environmental preferences (Spidle et al., 1994; Claxton and Mackie, 1998).

A number of studies have compared $D$. rostriformis bugensis with $D$. polymorpha, and results indicate that $D$. rostriformis bugensis has a higher assimilation efficiency (Baldwin et al., 2002), a lower respiration rate (Stoeckmann, 2003), and can spawn at colder temperatures (Roe and MacIsaac, 1997; Claxton and Mackie, 1998). Also, D. rostriformis bugensis has higher filtration rates during the warmer months (Diggins, 2001). These attributes theoretically allow it to colonize deep offshore regions where food availability is limited and temperatures are constantly cold, and to outcompete D. polymorpha in shallow, warm regions where food availability has been reduced by dreissenid-filtering activities (Wilson et al., 2006).

In this paper, we document changes in population density and biomass of $D$. rostriformis bugensis and D. polymorpha in southern Lake Michigan between 1992 and 2008. Based on long-term sampling, we knew that densities of $D$. polymorpha were declining and those of $D$. 
rostriformis bugensis were increasing in this portion of Lake Michigan since the early 2000s (Nalepa et al., 2009). So besides documenting recent population shifts, we also compared the nutritional state (relative tissue mass and biochemical content) of the two species in nearshore and offshore habitats. Our goals were to better understand the relationship between nutritional state and dreissenid population trends as $D$. polymorpha was displaced by $D$. rostriformis bugensis, and also to perhaps better predict the potential for future population growth of $D$. rostriformis bugensis in the offshore region. Further, we examined seasonal spawning patterns, recruitment, and metabolic activity (RNA/DNA and ETS) of D. rostriformis bugensis at sites above $(25 \mathrm{~m})$ and below the thermocline $(45 \mathrm{~m})$.

\section{Methods}

Population trends in D. polymorpha and D. rostriformis bugensis in the southern basin of Lake Michigan were derived from surveys at 40 sites that were part of a long-term benthic monitoring program (Fig. 1; Nalepa 1989; Nalepa et al., 1998). D. polymorpha was first reported in southern Lake Michigan in 1989 (Marsden et al., 1993), and our initial post-Dreissena sampling at the 40 sites occurred in 1992-1993. Thereafter, we sampled every year between 1998 and 2008. Sites were sampled in spring, summer, and fall in 1992, 1993,
1998, 1999, 2004, and 2005; otherwise, samples were collected in late summer/fall.

Samples at each site were taken in triplicate with a Ponar grab ( sampling area $=0.046 \mathrm{~m}^{2}$ ). Sediments were washed through an elutriation device fitted with a $0.5-\mathrm{mm}$ mesh screen, and retained residue preserved in $5 \%$ formalin containing rose bengal stain. In the laboratory, all dreissenids were picked and counted under a lowpower magnifier lamp $(1.5 \times)$. Samples with extremely high numbers were subsampled by selecting a random quadrate of individuals that were evenly distributed in a gridded tray. For purposes of analysis, the 40 sites were placed into four depth intervals: $16-30 \mathrm{~m}(n=11), 31-$ $50 \mathrm{~m}(n=12), 51-90 \mathrm{~m}(n=11)$, and $>90 \mathrm{~m}(n=6)$. These depth intervals represent $22.6 \%, 11.6 \%, 32.2 \%$, and $33.6 \%$ of the total area of the southern basin.

Dreissenids were collected for assessment of nutritional state at sites along two depth transects in 2004 and 2008. Two sites were located off Waukegan, IL, and two sites were located off Muskegon, MI. The Waukegan sites were included in the long-term sampling program and were at $20 \mathrm{~m}\left(\mathrm{H}-8 ; 42^{\circ} 23.92^{\prime} \mathrm{N}, 87^{\circ} 46.25^{\prime} \mathrm{W}\right)$ and $45 \mathrm{~m}$ (B-7; $42^{\circ} 22.00^{\prime} \mathrm{N}, 87^{\circ} 40.00^{\prime} \mathrm{W}$ ), whereas the Muskegon sites were at $25 \mathrm{~m}\left(\mathrm{M}-25 ; 43^{\circ} 12.00^{\prime} \mathrm{N}, 86^{\circ} 22.677^{\prime} \mathrm{W}\right)$ and $45 \mathrm{~m}\left(\mathrm{M}-45 ; 43^{\circ} 11.43^{\prime} \mathrm{N}\right.$, $86^{\circ} 25.72$ 'W) (Fig. 1). These sites were considered representative of the west and east sides of the basin, respectively. Both species were

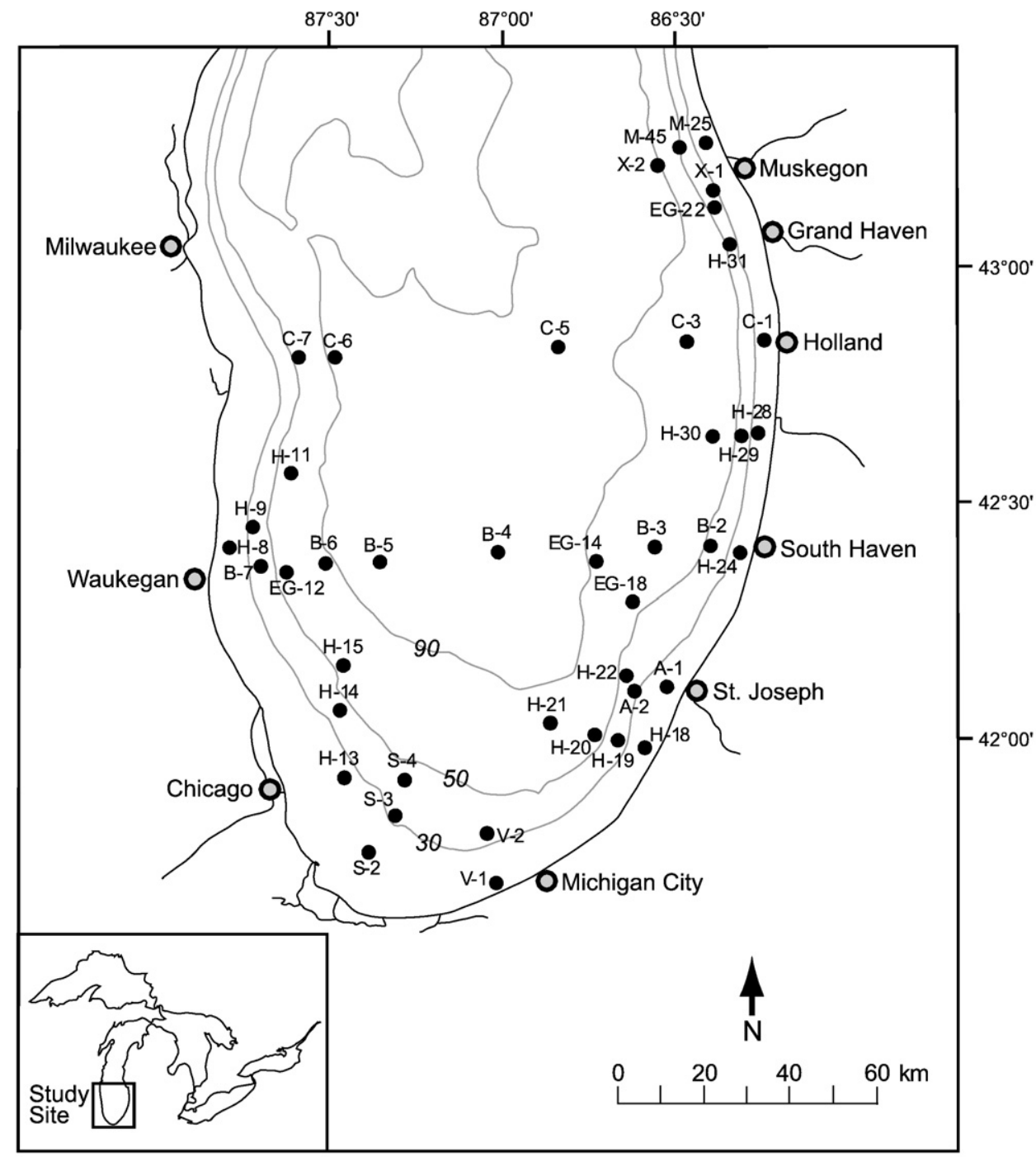

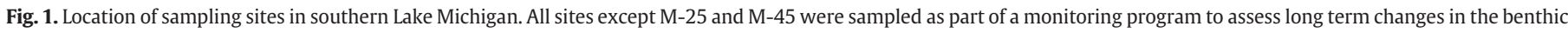

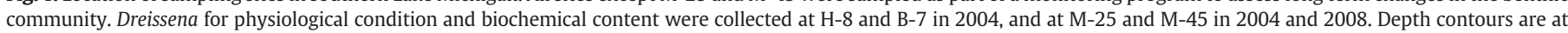
$30 \mathrm{~m}, 50 \mathrm{~m}$, and $90 \mathrm{~m}$. 
collected at all four sites in 2004, but only D. rostriformis bugensis was collected in 2008 and only at the two Muskegon sites. By 2008, D. polymorpha was very rare. In 2004, the Waukegan sites were sampled on four dates (May 27, Jul 1, Aug 25, and Sep 29), and the Muskegon sites were sampled on seven dates (Apr 20, Jun 3, Jun 23, Jul 21, Aug 31, Sep 21, and Oct 27). In 2008, the Muskegon sites were sampled on eight dates (Apr 8, Apr 30, Jun 4, Jul 7, Aug 12, Sep 2, Sep 29, and Nov $3)$. On each sampling date regardless of year, dreissenids were collected with either a Ponar grab or a benthic sled, gently rinsed in lake water, placed in coolers, and kept at $4{ }^{\circ} \mathrm{C}$ during transport back to the laboratory. In addition to collecting live animals, triplicate Ponar grabs and duplicate vertical net tows were taken on each date in 2008 at Stations M-25, M-45, and X-2 (93 m; $\left.43^{\circ} 12.00^{\prime} \mathrm{N}, 86^{\circ} 31.00^{\prime} \mathrm{W}\right)$. The grab samples were washed through a $0.5-\mathrm{mm}$ mesh net, and retained mussels were preserved and later counted as given above. It was initially planned to collect live mussels at X-2 for nutritional state, but too few mussels of various sizes were present.

The vertical net tows were taken to obtain estimates of dreissenid veligers. A conical plankton net $(64-\mu \mathrm{m}$ mesh openings, $1.5 \mathrm{~m}$ long, $0.3 \mathrm{~m}$ diameter) was hauled vertically from $1 \mathrm{~m}$ off the bottom to the surface; actual distance of the net haul was determined with a block/ cable metering system. Net contents were preserved in 5\% sugared formalin. In the laboratory, a subsample of a known sample volume was taken with a Hensen-Stempel pipette so that at least 100 veligers or $10 \%$ of the sample were counted per tow. On each sampling date in 2008 , bottom water temperatures ( $1 \mathrm{~m}$ above bottom) were measured with a SeaBird CTD. Measurements were taken at $15 \mathrm{~m}$ and $45 \mathrm{~m}$ (M-45) except on Sept 29 when temperatures were taken at $25 \mathrm{~m}$ (M-25) instead of at $15 \mathrm{~m}$. For purposes of this study, it was assumed that bottom temperatures at $15 \mathrm{~m}$ and $25 \mathrm{~m}$ were similar. These depths are above the thermocline in this region of Lake Michigan, and the water column is horizontally well mixed; bottom temperatures undergo broad fluctuations because of seiches, longshore currents, and upwellings/downwellings (Mozley and Winnell, 1975).

Within 48 hours after collection, live mussels were separated into five size categories based on relative shell length $(9-12 \mathrm{~mm}, 13-$ $15 \mathrm{~mm}, 16-18 \mathrm{~mm}, 19-21 \mathrm{~mm}$, and $22-25 \mathrm{~mm}$ ). Five individuals in each size category were cleaned of all shell debris, blotted dry, and then weighed to obtain whole, wet weight. After removal from the shell, soft tissue was placed into a combusted, preweighed aluminum planchet, dried at $60^{\circ} \mathrm{C}$ for at least $48 \mathrm{~h}$, and weighed to determine shell-free dry weight (DW). Tissues were then ashed at $550{ }^{\circ} \mathrm{C}$ for $1 \mathrm{~h}$ and weighed again for determination of ash-free-dry-weight (AFDW). The corresponding shell was measured (length; SL), dried at room temperature for at least $48 \mathrm{~h}$, and weighed.

These measurements of soft tissue and shell were used to determine the length-weight relationship and the condition index $(\mathrm{CI})$. The former is defined by the general allometric relationship $\mathrm{AFDW}=a \mathrm{SL}^{b}$ and presented as $\log _{\mathrm{e}} \mathrm{AFDW}(\mathrm{mg})=b+a \log _{\mathrm{e}} \mathrm{SL}(\mathrm{mm})$. The relationship has been frequently used as an index of nutritional state in dreissenids, with the weight of a standard $15-\mathrm{mm}$ mussel providing a convenient way to compare the state of individuals in different populations (Nalepa et al., 1993, 1995; Chase and Bailey, 1999a). The condition index (CI) is often used to assess the nutritional state of marine bivalves (Austin et al., 1993; Rheault and Rice, 1996; Mercado-Silva, 2005) and is calculated as follows:

$\mathrm{CI}=\frac{\text { dry soft tissue wt }(\mathrm{g}) \times 1000}{\text { internal shell capacity }(\mathrm{g})}$

The internal shell capacity is determined by subtracting dry shell weight from whole wet weight (soft tissue and shell) of a cleaned animal (Crosby and Gale, 1990). In essence, this index assesses the proportion of available internal shell cavity that is utilized by soft tissue and is useful in comparing bivalve species with different shell dimensions (width vs. length), as is the case for D. rostriformis bugensis and D. polymorpha (Dermott and Munawar, 1993). Since whole wet weight includes unassociated water within the shell cavity, some error is introduced when the shell opens and this free water is lost. However, we assumed that the number of these "gapped" individuals is small and random between the two species.

In addition to determining $\mathrm{AFDW} / \mathrm{SL}$ and $\mathrm{CI}$, total lipid and glycogen content were measured in both species in 2004 and in $D$. rostriformis bugensis in 2008. ETS (electron transport system), RNA/DNA (ribonucleic acid/deoxyribonucleic acid), and reproductive status were measured in D. rostriformis bugensis only in 2008. In 2004, soft tissue from 3 to 10 individuals in each of the three largest size categories of each species were placed into cryogenic vials and kept frozen at $-80^{\circ} \mathrm{C}$ until analysis. In 2008, four individuals in each of the three largest size categories were separately placed into vials for each analysis $(n=12$ for each variable), and vials were stored at $-80^{\circ} \mathrm{C}$.

Lipid content was determined by chloroform: methanol extraction followed by subsequent analysis using the microcolorimetric SPV approach (sulfophosphovanillan). Tissue samples were taken from the freezer and freeze-dried. Once dry, the tissue was pulverized, and a 2- to 5-mg subsample (measured to nearest $0.001 \mathrm{mg}$ ) was placed into a glass test tube $(50 \mathrm{~mm} \times 6 \mathrm{~mm})$ followed by the addition of $200 \mu \mathrm{L}$ of chloroform/methanol (2:1). Samples were homogenized for $30 \mathrm{~s}$ at $5000 \mathrm{rpm}$ using a variable-speed rotary tool (Dremel model no. $380-5$ ) with a glass bead pestle while immersed in ice to minimize evaporation. This homogenate was decanted into a $1.5-\mathrm{mL}$ conical centrifuge tube. Another $200 \mu \mathrm{L}$ of the $2: 1$ chloroform/methanol extraction solvent was added to the centrifuge tube as a rinse, homogenized briefly $(\sim 5 \mathrm{~s})$, and decanted to a total extract volume of $400 \mu \mathrm{L}$ (Gardner et al., 1985). To purify the lipid extract, $200 \mu \mathrm{L}$ of $0.9 \%$ $\mathrm{NaCl}$ solution was added to each sample, which was then mixed by vortexing (Folch et al., 1956). Centrifuge tubes were then placed in an Eppendorf centrifuge for $15 \mathrm{~s}$ at $8000 \mathrm{rpm}$, or a relative centrifugal force (G-force) of 5220. At this G-force, the phase separation occurs almost immediately, and increasing time did not improve separation in controlled trials. This phase separation results in nonlipid compounds and methanol being partitioned into the upper aqueous phase and the lipid-chloroform extract in the lower organic phase. From this organic lower phase, a microsampling pipette was used to remove a $100-\mu \mathrm{L}$ aliquot for microcolorimetric SPV analysis.

Microcolorimetric SPV analysis followed the methods of Van Handle (1985). Culture tubes ( $13 \mathrm{~mm} \times 100 \mathrm{~mm}$ ) containing $100 \mu \mathrm{L}$ of lipid extract were heated at $100{ }^{\circ} \mathrm{C}$ for $15 \mathrm{~min}$ on a dry bath heater to remove the chloroform solvent. We made certain to get complete evaporation of the chloroform as it has a positive interference with the phosphovanillin reagent. Then, $0.25 \mathrm{~mL}$ of $96 \% \mathrm{H}_{2} \mathrm{SO}_{4}$ was added to the bottom of the culture tube to make complete contact with the lipid residue, and samples were then vortexed and heated for $10 \mathrm{~min}$ at $100{ }^{\circ} \mathrm{C}$ on a dry bath heater. Five milliliters of the colorimetric SPV reagent ( $3 \mathrm{~g}$ vanillin, $0.5 \mathrm{~L}$ deionized water, $2 \mathrm{~L}$ concentrated phosphoric acid, stored in the dark) was added in each tube and thoroughly mixed by vortexing. After sitting at room temperature for 30 min, the absorbance $(A)$ was measured, using a Turner spectrophotometer. Solvent blanks were run through the entire procedure and used to "zero" the spectrophotometer. We used pure cod liver oil dissolved in 2:1 chloroform/methanol solvent mixture $(10 \mathrm{mg} / \mathrm{mL})$ as a stock standard. Working volumes of 0 (blank), 10, 20, 30, 40, and $50 \mu \mathrm{L}$ of this standard solution were used to develop a standard curve for lipids (absorbance ( $A, \mathrm{~nm}$ ) vs. mass of the standard $(\mathrm{mg})$ ), with the percent dry mass of lipids (PL) calculated as follows:

$\mathrm{PL}=\left(A^{*} V_{\mathrm{p}}^{*} 100\right) /\left(V_{\mathrm{s}}^{*} S_{\mathrm{s}}^{*} M_{\mathrm{f}}\right)$,

where $V_{\mathrm{p}}, V_{\mathrm{s}}$, and $M_{\mathrm{f}}$ are as described earlier $\left(V_{\mathrm{s}}=100 \mu \mathrm{L}\right.$ in this study), $A(\mathrm{~nm})$ is the absorbance at $525 \mathrm{~nm}, S_{\mathrm{s}}$ is the slope of the standard's regression line $(\mathrm{nm} / \mathrm{mg}), M_{\mathrm{f}}$ is the measured mass of the dry mussel sample ( $\mathrm{mg}$ ), and $V_{\mathrm{p}}$ is the volume ratio between extract fraction used for colorimetric SPV reactions and the total solvent 
mixture used for extraction. Lipid content was reported on a percent dry weight basis.

After freeze-drying, whole tissue samples for glycogen analysis were weighed so that the volume of glycogen buffer (phosphate) could be predetermined to keep the homogenate within the range of $1-2 \mathrm{mg} / \mathrm{mL}$. Methods followed those of Roehrig and Allred (1974) for the reduction of glycogen to glucose, and Sigma Kit 510 was used for glucose analysis. Tissues were homogenized in $0.05 \mathrm{~m}$ phosphate buffer $(\mathrm{pH} 4.8-5.0)$ in a $30-\mathrm{mL}$ Teflon/glass tissue grinder over ice for $30 \mathrm{~s}$, which was then followed by heat exposure in boiling water for $90 \mathrm{~s}$. A 3-mL aliquot of homogenate was transferred into ultra centrifuge tubes and centrifuged at $10,000 \times g$ for $20 \mathrm{~min}$ at $0{ }^{\circ} \mathrm{C}$. A $0.5-\mathrm{mL}$ aliquot was transferred from the centrifuge tube into a $13 \times 100-\mathrm{mm}$ test tube and combined with $0.5 \mathrm{~mL}$ of amyloglucosidase. The mixture was vortexed lightly, and then incubated in a water bath at $37^{\circ} \mathrm{C}$ for $2 \mathrm{~h}$. Also incubated were amyloglucosidase blanks (no glycogen) and glycogen standards made from Mytilus. After incubation, $0.5 \mathrm{~mL}$ was transferred to another test tube and incubated with $2.5 \mathrm{~mL}$ of glucose oxidase/peroxidase (GO/PO) enzymes at $37^{\circ} \mathrm{C}$ for $30 \mathrm{~min}$. GO/PO blanks ( $0.5 \mathrm{~mL}$ buffer and $2.5 \mathrm{~mL} \mathrm{GO} / \mathrm{PO}$ ) and glucose standards with $\mathrm{GO} / \mathrm{PO}$ were also incubated. All absorbances were read with a Turner spectrophotometer and reported on a percent dry weight basis.

Tissues samples for ETS analysis were lightly blotted and wet weights determined before being frozen and stored at $-80^{\circ} \mathrm{C}$. Methods for ETS analysis followed those of Bämstedt (1980, 2000). At the time of analysis, tissue samples were thawed and the entire sample homogenized in $0.1 \mathrm{M}$ phosphate buffer. The volume of the buffer was varied to keep a homogenate concentration of $2-5 \mathrm{mg} / \mathrm{mL}$. Three milliliters of the homogenate was transferred to a centrifuge tube and clarified at $10,000 \times g$ for $10 \mathrm{~min}$ in a refrigerated centrifuge at $0{ }^{\circ} \mathrm{C}$. One milliliter of the resulting supernatant was pipetted into each of two $16 \times 100-\mathrm{mm}$ culture tubes, with one of the tubes receiving $1 \mathrm{~mL}$ iodonitrotetrazolium reagent, and the other receiving phosphate buffer to serve as a turbidity blank. These tubes were then incubated at $20^{\circ} \mathrm{C}$. After $20 \mathrm{~min}$, the reaction was stopped with $1-\mathrm{mL}$ quench solution, and absorbances measured at $490 \mathrm{~nm}$ using a Turner spectrophotometer. The turbidity blank was used to zero the spectrophotometer for each individual sample. ETS was determined according to the following equation:

$\begin{array}{ll}\text { ETS } & (A / C) \times(60 / \mathrm{I}) \times((\mathrm{V} \times \mathrm{H}) /(\mathrm{S} \times \mathrm{M})) \times(32 / 2) \\ \text { ETS } & \begin{array}{l}\text { electron transport system }\left(\text { activity measured as } \mu \mathrm{gO}_{2} \mathrm{~g} / \text { wet }\right. \\ \text { wt } / \mathrm{h})\end{array} \\ A & \begin{array}{l}\text { corrected sample absorbance }\left(\mathrm{cm}^{-1}\right) \\ \text { constant molar absorbance for INT-formazan determined by } \\ \text { standard curve }(\mu \mathrm{mol} / \mathrm{mL} / \mathrm{cm})\end{array} \\ & \begin{array}{l}\text { incubation time }(\text { minutes }) \\ \text { I }\end{array} \\ \mathrm{V} & \text { final reaction volume }(\mathrm{mL}) \\ \mathrm{H} & \text { total homogenate volume }(\mathrm{mL}) \\ \mathrm{S} & \text { incubated volume }(\mathrm{mL})\end{array}$

Tissue samples for nucleic acid analysis were extracted immediately upon removal from the $-80{ }^{\circ} \mathrm{C}$ freezer. The extraction was modified from established protocols for measuring nucleic acids (Gorokhova and Kyle, 2002; Hook et al., 2008) to allow the inclusion of the whole mussel, which ranged in wet weight between 30 and $300 \mathrm{mg}$. Tissue samples were placed in $5 \mathrm{~mL}$ extraction buffer ( $1 \% \mathrm{~N}$ lauroyl sarcosine sodium salt in TE buffer) and homogenized over ice using a Teflon pestle and glass tube grinder. To achieve working concentrations similar to previous studies (Gorokhova and Kyle, 2002; Hook et al., 2008), a 100- $\mu$ L subsample of the raw extract was combined with $1400 \mu \mathrm{L}$ of extraction buffer in a conical snap cap centrifuge tube. After homogenization, samples were subjected to three repeated sequences of ultrasonic (30 s) and ice (1 min) baths. Samples were then put on a shaker table at $170 \mathrm{rpm}$ at room temperature for $2 \mathrm{~h}$. Each homogenate was assayed in triplicate using a microplate fluorescence reader $\left(\mathrm{FL}_{\mathrm{x}} 800\right.$ Biotek Instruments, filters: $485 \mathrm{~nm}$ for excitation and $528 \mathrm{~nm}$ for emission) and 96-well black flat bottom plates. Plates were scanned with $1 \mathrm{~s}$ well measurement time and 10 measurements per well. Plates were also loaded in duplicate with RNA standards ranging from 0.16 to $2.57 \mu \mathrm{g} / \mathrm{mL}$, DNA standards ranging from 0.04 to $0.68 \mu \mathrm{g} / \mathrm{mL}$, blanks, and negative controls. The fluorescence of each well was first quantified after RiboGreen addition ( $70 \mu \mathrm{L} /$ well; $5 \mathrm{~min}$ incubation at room temperature) and then for a second time after RNase addition ( $5 \mu \mathrm{L} /$ well; 30 min incubation at $37^{\circ} \mathrm{C}$ ). The first fluorescence gave a measure of total nucleic acids, while the second gave a measure of DNA since RNA in each well was digested by RNase. The second measure was then subtracted from the first to obtain only DNA fluorescence. Each sample's fluorescence was then compared to the standard curve to quantify the amount of RNA and DNA in each subsample.

Reproductive status of $D$. rostriformis bugensis was determined at $25 \mathrm{~m}(\mathrm{M}-25)$ and $45 \mathrm{~m}$ (M-45) on each date in 2008. Within $48 \mathrm{~h}$ of collection, the gonads of 10 female mussels of at least $20 \mathrm{~mm}$ in shell length (range $20-26 \mathrm{~mm}$ ) were examined under $100 \times$ magnification using a squash mount preparation. Development stage of the oocytes was categorized as given in Nichols (1993): Stage 1, no nuclei or germinal vesicle; Stage 2, visible nuclei but no germinal vesicle; Stage $3,<50 \%$ of oocytes have nuclei and germinal vesicle; Stage $4,>50 \%$ of oocytes have nuclei and germinal vesicle: Stage 5, only a few Stage 4 oocytes remain (spawning has occurred). The reproductive status was reported as the percentage of individuals at each stage.

Population biomass was estimated separately for D. polymorpha and $D$. rostriformis bugensis from size frequencies and derived lengthweight relationships. Shell lengths of mussels were measured at 18 of the 40 monitoring sites in each year between 1998 and 2008 (late summer/fall only). These sites were considered representative of the southern basin and chosen based on depth and location: $\mathrm{C}-1, \mathrm{H}-8, \mathrm{H}-$ 13, and $\mathrm{H}-24$ in the 16 - to 30-m interval; B-2, B-7, H-14, H-19, and H31 in the 31- to $50-\mathrm{m}$ interval; $\mathrm{B}-3, \mathrm{~B}-6, \mathrm{H}-15, \mathrm{H}-20$, and $\mathrm{H}-21$ in the 51- to $90-\mathrm{m}$ interval; and $\mathrm{B}-4, \mathrm{~B}-5$, and $\mathrm{X}-2$ in the $>90-\mathrm{m}$ interval. Mussels in each replicate sample were measured and then binned into 1-mm size categories from 1 to $33 \mathrm{~mm}$. When the number of mussels in an individual sample was large, it was subsampled as described above. The minimum number of mussels measured in each subsample was 100. To determine total biomass (as AFDW), the number of individuals in each size category was multiplied by the AFDW of an individual within that category (midshell length), and all category weights were summed. Weight per midshell length in each size category was calculated from the length-weight regressions determined in 2004 and 2008. Two regressions were used for $D$. polymorpha, one for sites in the 16- to $30-\mathrm{m}$ interval, and the other for sites in the three deeper intervals. These two regressions represented relationships above and below the thermocline, respectively. The former regression was derived from mussels collected at Stations $\mathrm{H}-8$ and M-25 on all dates in 2004, and the latter regression was derived from mussels collected at Stations B-7 and M-45, also on all dates in 2004. The regression used for D. rostriformis bugensis depended on depth interval as well as sampling year. For years between 1998 and 2004, depth-specific regressions were derived from mussels from the same sites as for D. polymorpha on all sampling dates in 2004. For years between 2005 and 2008, the regression used was derived from mussels collected on all dates in 2008. As given, mean biomass at each interval is based on estimates from all 40 sites. Biomass at sites where mussels were not measured $(n=22)$ was estimated by first determining the mean proportion of the population within each size category by depth interval and year for the measured sites, multiplying the proportion by total density at the nonmeasured sites, and then determining category-specific weights as above.

Yearly changes in size frequencies over the period 1998-2008 for both $D$. polymorpha and $D$. rostriformis bugensis were examined by binning individuals into $5-\mathrm{mm}$ size categories $(0-5 \mathrm{~mm}, 5-10 \mathrm{~mm}$, 

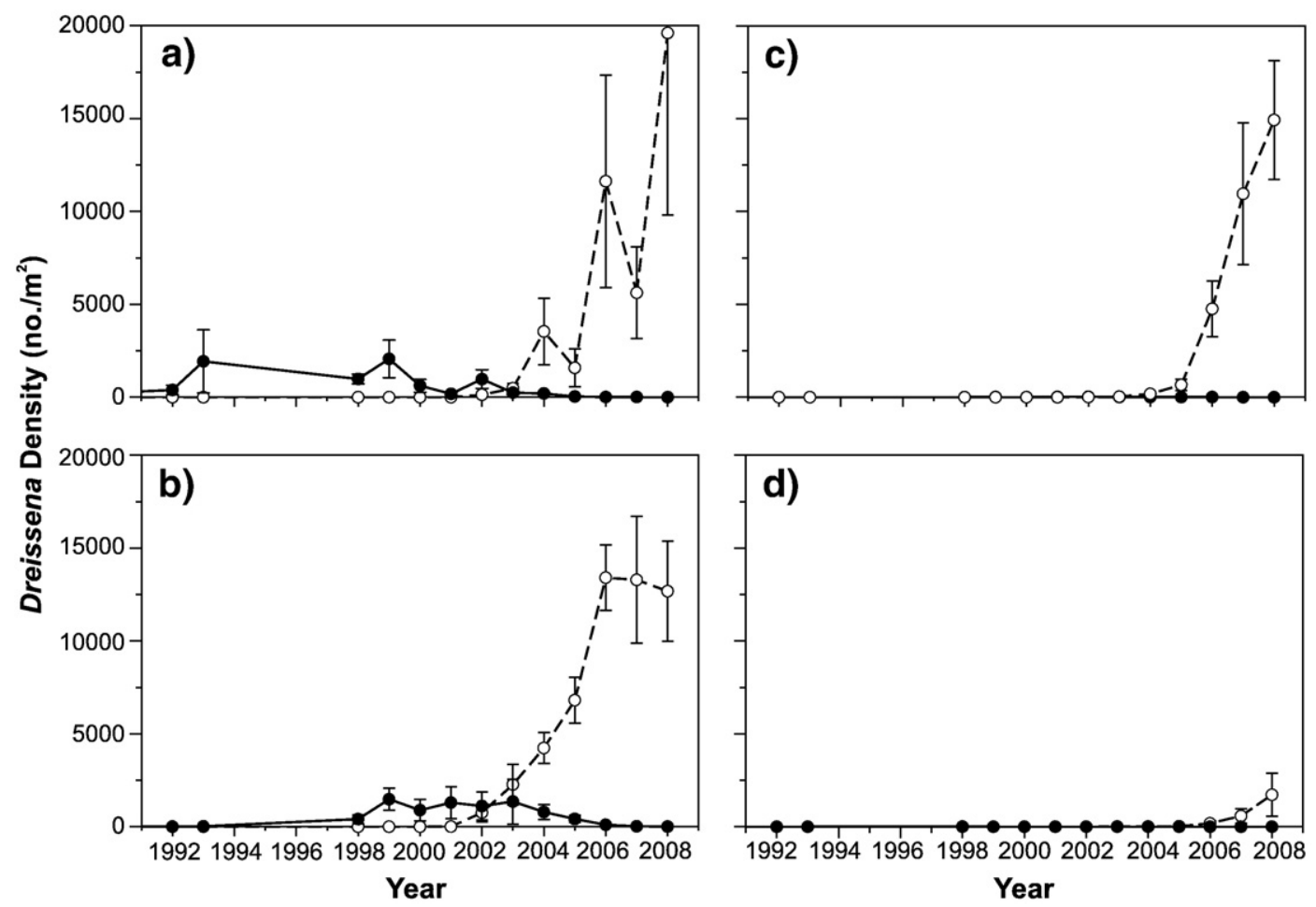

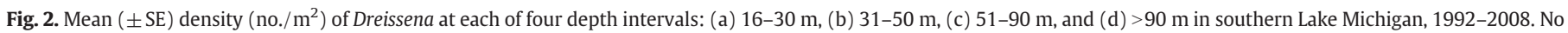
samples were collected in 1994-1997. Dreissena polymorpha = solid circle/solid line; D. rostriformis bugensis $=$ open circle/dashed line.

10-15 mm, 15-20 mm, 20-25 mm, >25 mm), and then determining the mean percentage within each size category. Size frequencies were only determined for those years and depth intervals in which mean densities exceeded $100 / \mathrm{m}^{2}$. Seasonal changes in size frequencies in
2008 were determined from mussels collected in the Ponar grab at $\mathrm{M}-25, \mathrm{M}-45$, and X-2.

Differences between depths (sites) and years for indicators of nutritional state were tested using ANOVA (two-way) or a paired
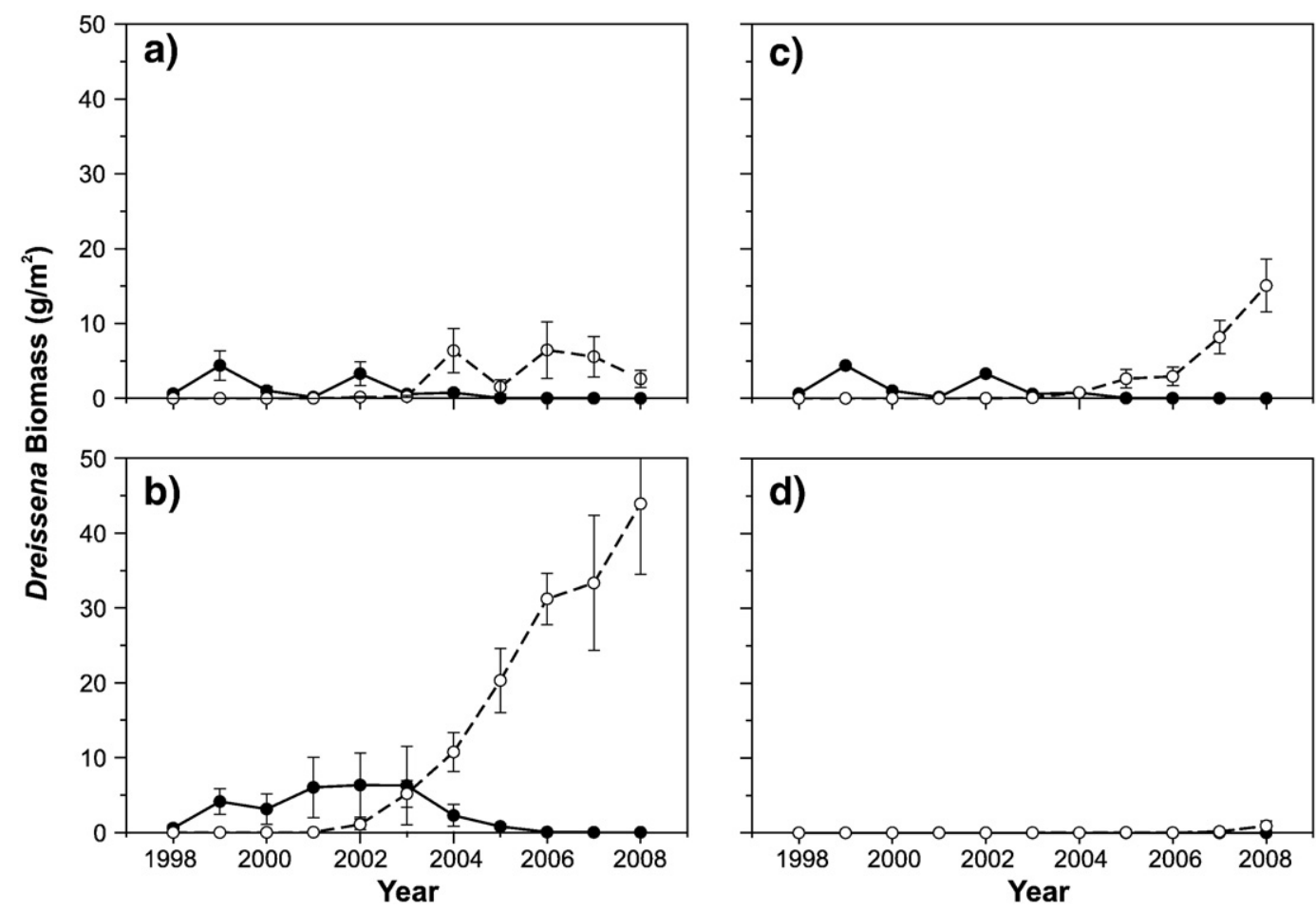

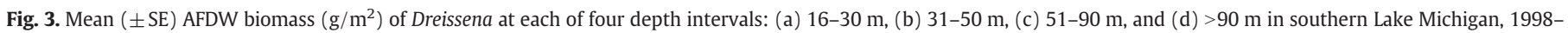
2008. Dreissena polymorpha $=$ solid circle/solid line; $D$. rostriformis bugensis $=$ open circle/dashed line 
Table 1

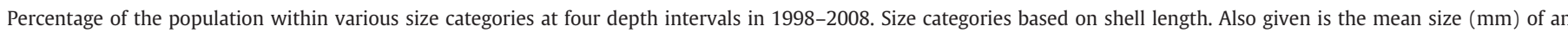
individual in the population. Dreissena polymorpha =(D.p.), Dreissena rostriformis bugensis = D.r.b.

\begin{tabular}{|c|c|c|c|c|c|c|c|c|c|c|c|c|c|c|}
\hline \multirow[t]{3}{*}{ Depth/year } & \multicolumn{12}{|c|}{ Size Interval } & & \\
\hline & \multicolumn{2}{|c|}{$0-5 \mathrm{~mm}$} & \multicolumn{2}{|c|}{ 5-10 mm } & \multicolumn{2}{|c|}{$10-15 \mathrm{~mm}$} & \multicolumn{2}{|c|}{$15-20 \mathrm{~mm}$} & \multicolumn{2}{|c|}{$20-25 \mathrm{~mm}$} & \multicolumn{2}{|c|}{$>25 \mathrm{~mm}$} & \multicolumn{2}{|c|}{ Mean size } \\
\hline & D.p. & D.r.b. & D.p. & D.r.b. & D.p. & D.r.b. & D.p. & D.r.b. & D.p. & D.r.b. & D.p. & D.r.b. & $D p$ & D.r.b. \\
\hline \multicolumn{15}{|l|}{$16-30 \mathrm{~m}$} \\
\hline 1998 & 87.8 & - & 6.6 & - & 3.9 & - & 0.9 & - & 0.7 & - & 0.1 & - & 3.1 & - \\
\hline 1999 & 29.5 & - & 43.0 & - & 16.9 & - & 10.7 & - & 0.0 & - & 0.0 & - & 7.0 & - \\
\hline 2000 & 48.2 & - & 30.0 & - & 12.9 & - & 9.0 & - & 0.0 & - & 0.0 & - & 6.1 & - \\
\hline 2001 & 50.6 & - & 25.7 & - & 0.4 & - & 23.3 & - & 0.0 & - & 0.0 & - & 5.5 & - \\
\hline 2002 & 14.4 & - & 29.6 & - & 31.1 & - & 15.4 & - & 5.1 & - & 4.3 & - & 10.6 & - \\
\hline 2003 & 31.6 & - & 31.6 & - & 22.9 & - & 8.3 & - & 5.6 & - & 0.0 & - & 7.3 & - \\
\hline 2004 & 27.9 & 44.8 & 16.7 & 23.0 & 40.2 & 27.4 & 14.8 & 4.0 & 0.5 & 0.7 & 0.0 & 0.1 & 9.1 & 7.0 \\
\hline 2005 & - & 39.9 & - & 52.9 & - & 4.3 & - & 2.8 & - & 0.0 & - & 0.0 & - & 5.5 \\
\hline 2006 & - & 80.0 & - & 11.6 & - & 5.4 & - & 2.9 & - & 0.0 & - & 0.0 & - & 3.6 \\
\hline 2007 & - & 59.9 & - & 23.5 & - & 14.7 & - & 1.3 & - & 0.2 & - & 0.6 & - & 5.5 \\
\hline 2008 & - & 90.5 & - & 6.6 & - & 2.1 & - & 0.5 & - & 0.3 & - & 0.0 & - & 3.1 \\
\hline \multicolumn{15}{|l|}{$31-50 \mathrm{~m}$} \\
\hline 1998 & 69.8 & - & 25.2 & - & 3.3 & - & 1.4 & - & 0.3 & - & 0.0 & - & 5.0 & - \\
\hline 1999 & 19.1 & - & 38.0 & - & 19.3 & - & 23.1 & - & 0.5 & - & 0.0 & - & 8.5 & - \\
\hline 2000 & 31.0 & - & 31.8 & - & 27.4 & - & 7.4 & - & 1.9 & - & 0.4 & - & 8.8 & - \\
\hline 2001 & 2.9 & - & 24.2 & - & 32.3 & - & 34.2 & - & 5.9 & - & 0.5 & - & 12.7 & - \\
\hline 2002 & 17.5 & 53.7 & 10.9 & 39.4 & 33.9 & 2.0 & 18.7 & 1.4 & 18.8 & 3.6 & 0.2 & 0.0 & 12.7 & 5.5 \\
\hline 2003 & 28.7 & 43.3 & 28.1 & 18.3 & 15.7 & 23.3 & 16.5 & 13.9 & 8.6 & 1.2 & 2.5 & 0.0 & 8.7 & 8.1 \\
\hline 2004 & 36.0 & 44.1 & 35.1 & 29.4 & 21.9 & 17.6 & 6.6 & 6.9 & 0.2 & 1.6 & 0.2 & 0.3 & 7.6 & 7.2 \\
\hline 2005 & 31.5 & 36.9 & 44.9 & 22.3 & 11.5 & 15.2 & 12.0 & 22.3 & 0.0 & 3.1 & 0.0 & 0.2 & 6.5 & 8.7 \\
\hline 2006 & - & 53.0 & - & 20.5 & - & 10.1 & - & 8.2 & - & 7.8 & - & 0.4 & - & 6.9 \\
\hline 2007 & - & 37.5 & - & 27.1 & - & 19.9 & - & 11.9 & - & 3.3 & - & 0.3 & - & 8.4 \\
\hline 2008 & - & 33.4 & - & 22.2 & - & 19.6 & - & 18.3 & - & 5.7 & - & 0.8 & - & 9.7 \\
\hline \multicolumn{15}{|l|}{$51-90 \mathrm{~m}$} \\
\hline 2006 & - & 87.4 & - & 10.2 & - & 1.2 & - & 0.3 & - & 0.6 & - & 0.3 & - & 3.6 \\
\hline 2007 & - & 72.6 & - & 18.0 & - & 7.3 & - & 1.4 & - & 0.5 & - & 0.2 & - & 4.6 \\
\hline 2008 & - & 65.0 & - & 14.1 & - & 18.5 & - & 2.1 & - & 0.2 & - & 0.1 & - & 5.1 \\
\hline \multicolumn{15}{|l|}{$>90 \mathrm{~m}$} \\
\hline 2007 & - & 68.0 & - & 31.8 & - & 0.0 & - & 0.2 & - & 0.0 & - & 0.0 & - & 3.9 \\
\hline 2008 & - & 83.6 & - & 11.5 & - & 3.3 & - & 0.2 & - & 0.1 & - & 0.4 & - & 3.9 \\
\hline
\end{tabular}

t-test. All indicators reported as percentages were transformed using the arcsine transformation before analysis.

\section{Results}

Yearly trends in density, biomass, and size frequency

Trends in densities of $D$. polymorpha and $D$. rostriformis bugensis between 1992 and 2008 at the four depth intervals are given in Fig. 2. Over the entire period, $D$. polymorpha was mainly found at sites $<50 \mathrm{~m}$. Mean densities of this species at $16-30 \mathrm{~m}$ peaked at $2064 / \mathrm{m}^{2}$ in 1999 , varied between $183 / \mathrm{m}^{2}$ and $971 / \mathrm{m}^{2}$ in $2000-2004$, and then declined to $0 / \mathrm{m}^{2}$ by 2008 . Temporal trends at $31-50 \mathrm{~m}$ were generally similar; mean densities peaked at $790-1477 / \mathrm{m}^{2}$ between 1999 and 2003 , and then declined to near $0 / \mathrm{m}^{2}$ by 2008 .
The decrease in densities of D. polymorpha after 2003 was temporally coincident with the expansion of $D$. rostriformis bugensis in the southern basin. D. rostriformis bugensis was first found in northern Lake Michigan in 1997 (Nalepa et al., 2001) but was not found in our study area until 2001. Initial densities increased at sites in the two shallowest intervals in 2001-2002, increased at sites in the 51- to $90-\mathrm{m}$ interval in 2005, and increased at sites in the $>90-\mathrm{m}$ interval in 2007 (Fig. 2). As of 2008, mean densities were still increasing at all intervals except at $31-50 \mathrm{~m}$. At this interval, mean densities were generally stable between 2006 and 2008, ranging between 12,600 and $13,400 / \mathrm{m}^{2}$. Greater mean density at $16-30 \mathrm{~m}$ in 2008 compared to $2007\left(19,614 / \mathrm{m}^{2}\right.$ vs. $5622 / \mathrm{m}^{2}$; Fig. 2$)$ was mostly a result of a large number of small, newly settled individuals at just two sites on the east side of the lake. Densities at C-1 and H-24 in 2008 were $80,196 / \mathrm{m}^{2}$ and $82,853 / \mathrm{m}^{2}$, respectively, and $>99 \%$ of individuals

Table 2

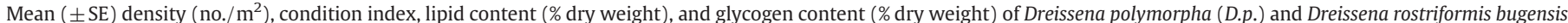
(D.r.p.) at sites on the east (M-25, M-45) and west (H-8, B-7) of southern Lake Michigan in 2004 and 2008 . Site depths: M-25=25 m, M-45=45 m, H-8 = $20 \mathrm{~m}, \mathrm{~B}-7=45 \mathrm{~m}$.

\begin{tabular}{|c|c|c|c|c|c|c|c|c|}
\hline \multirow[t]{2}{*}{ Year/site } & \multicolumn{2}{|c|}{ Density (no./m²) } & \multicolumn{2}{|c|}{ Condition index } & \multicolumn{2}{|l|}{ Lipid (\%) } & \multicolumn{2}{|c|}{ Glycogen (\%) } \\
\hline & D.p. & D.r.b. & D.p. & D.r.b. & D.p. & D.r.b. & D.p. & D.r.b. \\
\hline \multicolumn{9}{|l|}{2004} \\
\hline M-25 & $64 \pm 45$ & $963 \pm 291$ & $70.8 \pm 2.3$ & $82.2 \pm 1.9$ & $10.4 \pm 1.0$ & $14.3 \pm 0.9$ & $2.9 \pm 0.4$ & $2.7 \pm 0.3$ \\
\hline $\mathrm{M}-45$ & $942 \pm 511$ & $8,748 \pm 1,740$ & $38.9 \pm 1.0$ & $60.6 \pm 1.0$ & $10.0 \pm 0.3$ & $11.1 \pm 0.5$ & $1.6 \pm 0.2$ & $2.5 \pm 0.2$ \\
\hline $\mathrm{H}-8$ & $350 \pm 250$ & $674 \pm 558$ & $41.6 \pm 1.4$ & $60.8 \pm 2.2$ & $8.4 \pm 0.3$ & $8.3 \pm 0.5$ & $1.0 \pm 0.2$ & $1.3 \pm 0.2$ \\
\hline B-7 & $67 \pm 44$ & $533 \pm 148$ & $63.2 \pm 1.8$ & $89.7 \pm 1.9$ & $15.0 \pm 0.9$ & $16.2 \pm 1.3$ & $3.8 \pm 0.5$ & $3.1 \pm 0.3$ \\
\hline \multicolumn{9}{|l|}{2008} \\
\hline M-25 & $0 \pm 0$ & $4212 \pm 2,371$ & & $74.5 \pm 2.4$ & & $15.8 \pm 0.4$ & & $10.9 \pm 0.4$ \\
\hline $\mathrm{M}-45$ & $0 \pm 0$ & $13,023 \pm 1347$ & & $41.6 \pm 1.1$ & & $12.1 \pm 0.4$ & & $4.7 \pm 0.3$ \\
\hline $\mathrm{H}-8$ & $0 \pm 0$ & $1192 \pm 573$ & & & & & & \\
\hline B-7 & $0 \pm 0$ & $9060 \pm 2533$ & & & & & & \\
\hline
\end{tabular}


Table 3

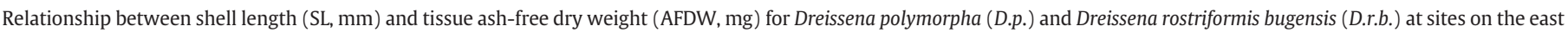

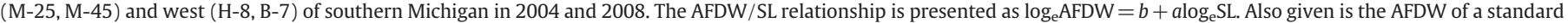
$15-\mathrm{mm}$ individual as derived from the determined relationship. Site depths: $\mathrm{M}-25=25 \mathrm{~m}, \mathrm{M}-45=45 \mathrm{~m}, \mathrm{H}-8=20 \mathrm{~m}, \mathrm{~B}-7=45 \mathrm{~m}$.

\begin{tabular}{|c|c|c|c|c|c|c|c|c|c|c|}
\hline \multirow[t]{2}{*}{ Year/site } & \multicolumn{2}{|l|}{$b$} & \multicolumn{2}{|l|}{$a$} & \multicolumn{2}{|l|}{$R^{2}$} & \multicolumn{2}{|l|}{$n$} & \multicolumn{2}{|c|}{$15-\mathrm{mm}$} \\
\hline & D.p. & D.r.b. & D.p. & D.r.b. & D.p. & D.r.b. & D.p. & D.r.b. & D.p. & D.r.b. \\
\hline \multicolumn{11}{|l|}{2004} \\
\hline M-25 & -5.054 & -6.545 & 2.658 & 3.195 & 0.752 & 0.883 & 148 & 150 & 8.53 & 8.20 \\
\hline M-45 & -4.720 & -6.674 & 2.394 & 3.174 & 0.828 & 0.936 & 149 & 148 & 5.23 & 6.83 \\
\hline $\mathrm{H}-8$ & -4.645 & -5.695 & 2.343 & 2.726 & 0.850 & 0.934 & 94 & 94 & 5.47 & 5.40 \\
\hline B-7 & -5.755 & -6.995 & 2.933 & 3.426 & 0.892 & 0.947 & 93 & 99 & 8.91 & 9.80 \\
\hline Overall & -5.226 & -6.535 & 2.651 & 3.143 & 0.776 & 0.874 & 484 & 491 & 7.05 & 7.21 \\
\hline \multicolumn{11}{|l|}{2008} \\
\hline M-25 & & -6.299 & & 3.193 & & 0.917 & & 199 & & 10.46 \\
\hline M-45 & & -5.469 & & 2.659 & & 0.928 & & 193 & & 5.65 \\
\hline
\end{tabular}

were $<5 \mathrm{~mm}$. Mean density at the other eight sites in this interval was only $5857 / \mathrm{m}^{2}\left(\mathrm{SE}=4055 / \mathrm{m}^{2}\right)$. Except for a few individuals at Station $\mathrm{H}-13$ (19 m depth), all individuals of $D$. rostriformis bugensis collected over the entire sampling period regardless of interval were the profunda phenotype.

In general, temporal trends in biomass paralleled those of density for both species. Mean biomass (AFDW) of $D$. polymorpha peaked in 2002 and then declined (Fig. 3). Maximum mean biomass was $6.3 \mathrm{~g} / \mathrm{m}^{2}$ at $31-50 \mathrm{~m}$ in 2002 . For $D$. rostriformis bugensis, mean biomass increased beginning in 2001 and continued to increase at the three deepest depth intervals through 2008. Maximum mean biomass was $43.9 \mathrm{~g} / \mathrm{m}^{2}$ at $31-50 \mathrm{~m}$ in 2008 . While trends in density and biomass were generally similar, there were some noted exceptions. The increase in mean density of D. rostriformis bugensis at 16-30 m between 2007 and 2008 was not accompanied by a corresponding increase in biomass. Also, while mean densities at 31-50 m were similar in 2007 and 2008, mean biomass was 31.8\% higher in 2008 compared to 2007 .

Year-to-year variation in size frequencies of both $D$. polymorpha and $D$. rostriformis bugensis at the different intervals is given in Table 1. Of interest are trends in the proportion of newly recruited individuals $(<5 \mathrm{~mm})$, since changes in the relative number of these small individuals would indicate whether recruitment in D. polymorpha and $D$. rostriformis bugensis varied with density shifts. For $D$. polymorpha, the mean percentage of individuals $<5 \mathrm{~mm}$ in the total population was highly variable between years, ranging from $27.9 \%$ to $87.8 \%$ at $16-30 \mathrm{~m}$, and from $2.9 \%$ to $69.8 \%$ at $31-50 \mathrm{~m}$. In contrast, the mean proportion of individuals $<5 \mathrm{~mm}$ in the $D$. rostriformis bugensis population was greater and less variable from year-to-year compared to $D$. polymorpha. At the two shallowest intervals, the mean proportion for D. rostriformis bugensis was $51.4 \%$ (coefficient of variation $=33.0 \%$; $n=12$ ), whereas the mean proportion for D. polymorpha was $34.4 \%$ (coefficient of variation $=71.5 \% ; n=15$ ). The proportion of $<5 \mathrm{~mm}$ individuals in the $D$. rostriformis bugensis population at depths deeper than $50 \mathrm{~m}$ was consistently greater than $65.0 \%$ and likely reflected the recent expansion (since 2005) of the population into the offshore region. In 2008, mean size was $3.1 \mathrm{~mm}, 9.7 \mathrm{~mm}, 5.1 \mathrm{~mm}$, and $3.9 \mathrm{~mm}$ at $16-30 \mathrm{~m}, 31-50 \mathrm{~m}, 51-90 \mathrm{~m}$, and $>90 \mathrm{~m}$, respectively.

\section{Comparisons of nutritional state and physical characteristics: $D$. polymorpha and $D$. rostriformis bugensis}

The nutritional state of both $D$. polymorpha and $D$. rostriformis bugensis (all profunda) were measured in 2004 when both species were present and relatively abundant. $D$. rostriformis bugensis had a higher condition index (CI) than D. polymorpha at each of the four sites sampled (H-8, B-7, M-25, and M-45), and this difference was significant $\left(F_{[1,1064]}=229.56, P<0.001\right.$; Table 2$)$. Overall, mean $\mathrm{CI}$ was 73.3 and 53.6, respectively, for the two species. Thus, on average, D. rostriformis bugensis had $36.5 \%$ more soft tissue relative to shell cavity volume than D. polymorpha. While the index was higher for D. rostriformis bugensis at each of the four sites, the relative difference was greater at $45 \mathrm{~m}$ than at 20-25 m. The difference between the shallow and deep depth was not significant $\left(F_{[1,1064]}=0.312, P=0.576\right)$, but there was a significant depth $\times$ transect interaction $\left(F_{[1,1064]}=397.296, P<0.001\right)$. At the Muskegon transect, both species had a higher $\mathrm{CI}$ at $25 \mathrm{~m}$ compared to $45 \mathrm{~m}$, but at the Waukegan transect, both species had a higher value at $45 \mathrm{~m}$ compared to $20 \mathrm{~m}$.

Differences between the two species were not as pronounced when AFDW-SL relationships were compared (Table 3). While regression slopes for the two species were significantly different (ANCOVA, $P<0.01$ ), the difference between species was most evident at $45 \mathrm{~m}$. Over all dates and sites, the weight of a standard $15-\mathrm{mm}$ individual of $D$. rostriformis bugensis and $D$. polymorpha were comparable ( $7.21 \mathrm{mg}$ vs. $7.05 \mathrm{mg}$ ).

Other physical characteristics of the shell and soft tissue of the two species are given in Table 4. Shell weight per unit shell length (SW/SL) was significantly lower in $D$. rostriformis bugensis $\left(F_{[1,1065]}=207.5\right.$, $P<0.01$ ). Mean SW/SL for $D$. rostriformis bugensis was about one-half

Table 4

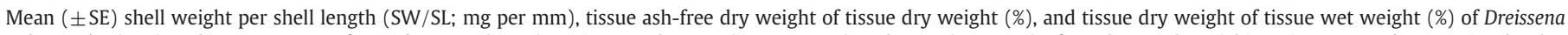

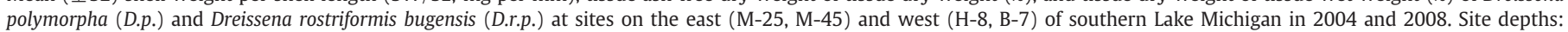
$\mathrm{M}-25=25 \mathrm{~m}, \mathrm{M}-45=45 \mathrm{~m}, \mathrm{H}-8=20 \mathrm{~m}, \mathrm{~B}-7=45 \mathrm{~m}$.

\begin{tabular}{|c|c|c|c|c|c|c|}
\hline \multirow[t]{2}{*}{ Year/site } & \multicolumn{2}{|l|}{$\mathrm{SW} / \mathrm{SL}$} & \multicolumn{2}{|c|}{ AFDW of DW (\%) } & \multicolumn{2}{|c|}{ DW of WW (\%) } \\
\hline & D.p. & D.r.b. & D.p. & D.r.b. & D.p. & D.r.b. \\
\hline \multicolumn{7}{|l|}{2004} \\
\hline M-25 & $14.2 \pm 0.7$ & $8.4 \pm 0.4$ & $65.7 \pm 0.5$ & $66.2 \pm 0.6$ & $7.1 \pm 0.2$ & $8.2 \pm 0.2$ \\
\hline $\mathrm{M}-45$ & $16.5 \pm 0.8$ & $6.7 \pm 0.3$ & $67.4 \pm 0.5$ & $69.9 \pm 0.6$ & $3.9 \pm 0.1$ & $6.1 \pm 0.1$ \\
\hline $\mathrm{H}-8$ & $10.0 \pm 0.6$ & $7.6 \pm 0.5$ & $65.8 \pm 0.8$ & $62.8 \pm 1.0$ & $4.2 \pm 0.1$ & $6.1 \pm 0.2$ \\
\hline B-7 & $20.7 \pm 1.3$ & $9.5 \pm 0.7$ & $64.8 \pm 0.5$ & $66.2 \pm 0.6$ & $6.3 \pm 0.2$ & $9.0 \pm 0.2$ \\
\hline \multicolumn{7}{|l|}{2008} \\
\hline M-25 & - & $9.0 \pm 0.4$ & - & $88.4 \pm 0.6$ & - & $7.5 \pm 0.2$ \\
\hline M-45 & - & $7.8 \pm 0.3$ & - & $87.8 \pm 1.7$ & - & $4.1 \pm 0.1$ \\
\hline
\end{tabular}



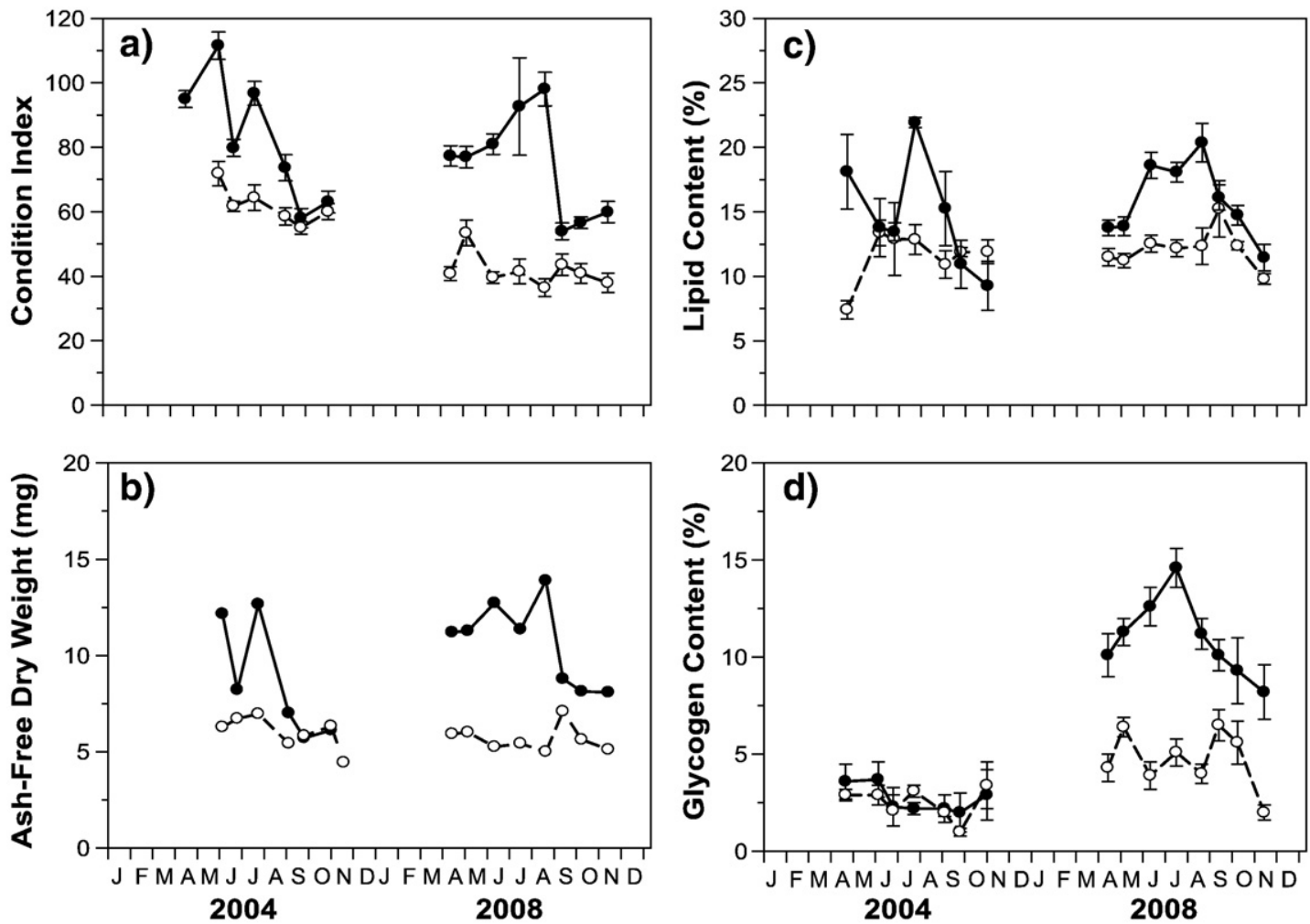

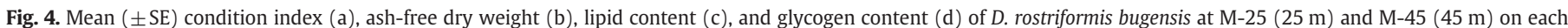

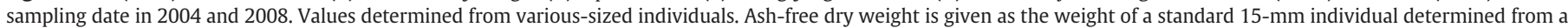
AFDW/SL regression determined on each sampling date. $\mathrm{M}-25=$ solid circle/solid line; $\mathrm{M}-45=$ open circle/dashed line.

that of $D$. polymorpha $(7.9 \mathrm{mg} / \mathrm{mm}$ vs. $15.3 \mathrm{mg} / \mathrm{mm})$. The percentage of dry weight relative to wet weight (DW/WW; tissue only) was significantly higher in $D$. rostriformis bugensis $\left(F_{[1,1065]}=171.2\right.$, $P<0.01$ ), but the percentage of ash-free dry weight relative to dry weight (AFDW/DW; tissue only) was not significantly different between the two species $\left(F_{[1,1065]}=2.1, P \leq 0.15\right)$.

$D$. rostriformis bugensis had a significantly higher lipid content than D. polymorpha $\left(F_{[1,155]}=6.40, P=0.012\right)$ regardless of depth or transect (interactions were not significant, $P>0.05$ ). Overall, mean lipid content of $D$. rostriformis bugensis was $12.4 \%$ compared to $10.7 \%$ for $D$. polymorpha (Table 2). Lipid content was significantly higher at $45 \mathrm{~m}$ compared to $20-25 \mathrm{~m}\left(F_{[1,155]}=25.664, P<0.001\right)$, but the depth $\times$ transect interaction was also significant $\left(F_{[1,155]}=59.174, P<0.001\right)$. As found for $\mathrm{CI}$, overall lipid content of the two species was higher at the shallow site compared to the deeper site at the Muskegon transect but higher at the deeper site compared to the shallow site at the Waukegan transect. Mean glycogen content was $2.4 \%$ and $2.3 \%$ in $D$. rostriformis bugensis and D. polymorpha, respectively, and this difference was not significant $\left(F_{[1,164]}=1.42, P=0.25\right.$; Table 2$)$.

\section{Yearly and seasonal trends in nutritional state of D. rostriformis bugensis}

Given the rapid and continued expansion of the $D$. rostriformis bugensis population between 2004 and 2008 in the southern basin (Fig. 2), we were interested in relative changes in its nutritional state over this 4-year period. Densities at $25 \mathrm{~m}(\mathrm{M}-25)$ and $45 \mathrm{~m}$ (M-45) over this period increased from $963 / \mathrm{m}^{2}$ to $4212 / \mathrm{m}^{2}$ and from $8748 / \mathrm{m}^{2}$ to $13,023 / \mathrm{m}^{2}$, respectively (Table 2 ). For both sampling depths, CI was significantly lower in 2008 than in $2004\left(F_{[1,735]}=243.04, P<0.001\right)$, but this difference was depth-dependent (year $\times$ depth interaction, $\left.F_{[1,735]}=58.68, P<0.001\right)$. The decline in $\mathrm{Cl}$ between years was greater at $45 \mathrm{~m}$ than at $25 \mathrm{~m}$ (Table 2 and Fig. $4 \mathrm{a}$ ). Consistent with a greater decline in $\mathrm{Cl}$ at $45 \mathrm{~m}$, the weight of a standard 15- $\mathrm{mm}$ individual at $45 \mathrm{~m}$ declined by $17 \%$ between the 2 years, but an increase was evident at $25 \mathrm{~m}$ (Table 3). Slopes of the AFDW/SL regressions were significantly different between 2004 and 2008 at $45 \mathrm{~m}$ (ANCOVA, $P<0.001$ ) but not at $25 \mathrm{~m}$ (ANCOVA, $P>0.05$ ).
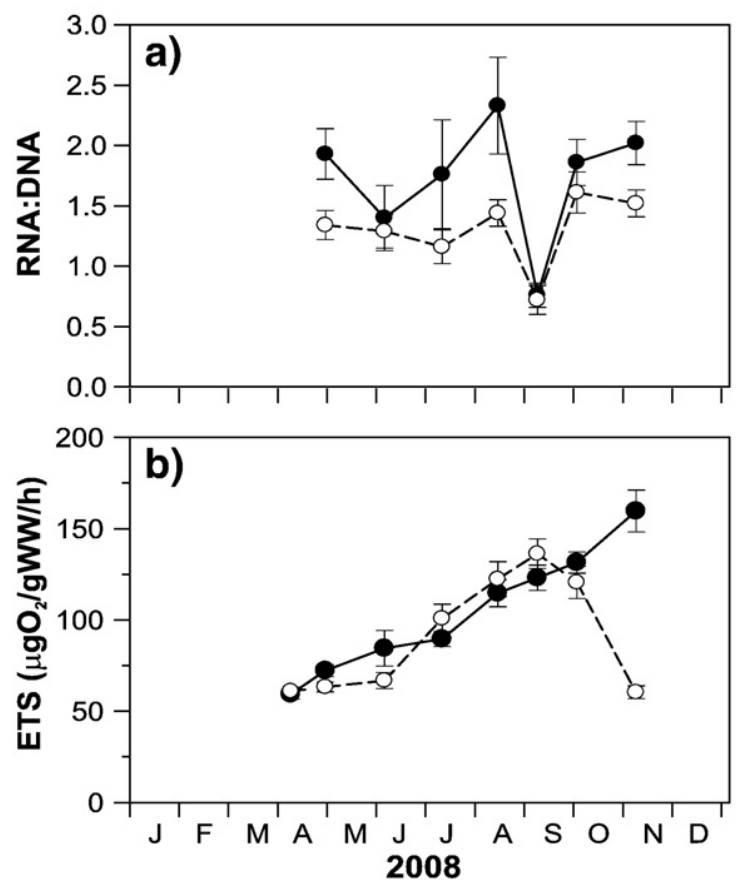

Fig. 5. Mean $( \pm \mathrm{SE})$ RNA/DNA ratio (a) and ETS (b) of D. rostriformis bugensis at M-25 $(25 \mathrm{~m})$ and $\mathrm{M}-45$ (45 m) on each sampling date in 2008. Values determined on various sized individuals on each sampling date. $\mathrm{M}-25=$ solid circle/solid line, $\mathrm{M}-45=$ open circle/dashed line. 


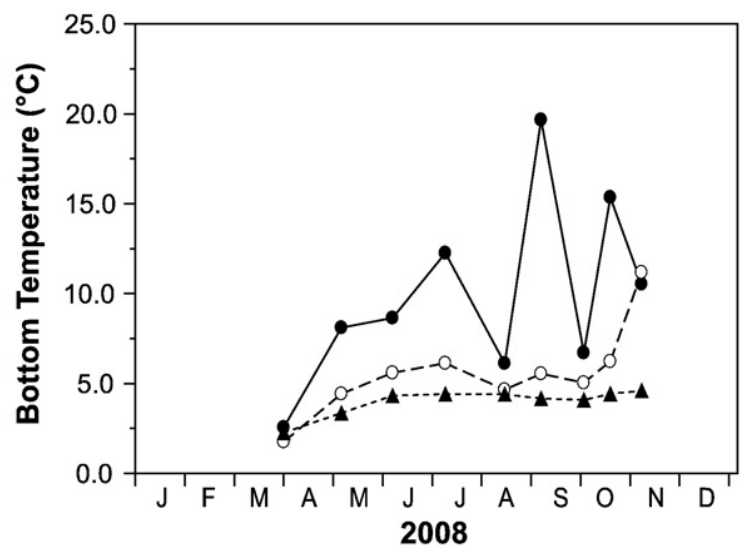

Fig. 6. Near-bottom water temperatures $\left(\mathrm{C}^{\circ}\right)$ at $\mathrm{M}-25(25 \mathrm{~m}), \mathrm{M}-45$ (45 m), and X-2 (93 m) on each sampling date in $2008 . \mathrm{M}-25=$ solid circle/solid line; $\mathrm{M}-45=$ open circle/ dashed line; $\mathrm{X}-2=$ solid triangle/dashed line.

While relative tissue mass based on $\mathrm{CI}$ and AFDW/SL tended to be lower in 2008 compared to 2004, lipid content was not significantly different between the 2 years $\left(F_{[1,86]}=1.84, P=0.18\right)$, and glycogen content was significantly higher in 2008 compared to $2004\left(F_{[1,86]}=\right.$ 62.31, $P<0.01$; Table 2). When depths were compared across years, both lipid and glycogen content were significantly higher at $25 \mathrm{~m}$ than at $45 \mathrm{~m}$ (lipid: $F_{[1,86]}=20.06, P<0.01$; glycogen: $F_{[1,86]}=8.28$, $P<0.01)$. For glycogen, however, there was a significant year $\times$ depth interaction $\left(F_{[1,86]}=10.56, P<0.01\right)$. Clearly, glycogen content was greater at $25 \mathrm{~m}$ than at $45 \mathrm{~m}$ in 2008 but not in 2004 (Table 2).

Seasonal trends in tissue mass and biochemical content varied between the two depths. At $25 \mathrm{~m}, \mathrm{CI}$ and AFDW/SL remained generally high until late summer and then rapidly declined in both 2004 and 2008 (Figs. 4a and b). Seasonal trends in lipid content were similar; values remained relatively high until late summer and then declined in both years (Fig. 4c). However, a consistent seasonal pattern between the 2 years was not apparent for glycogen (Fig. 4d). Whereas a defined seasonal pattern was not apparent in 2004, trends in 2008 were similar to lipid content. Seasonal patterns of all indicators were different at $45 \mathrm{~m}$ compared to $25 \mathrm{~m}$. CI was at a seasonal maximum in spring and then declined by late spring/early summer both years; AFDW/SL and lipid content followed this general seasonal pattern in 2004, but in 2008, a late summer increase was also evident (Fig. 4). As at $25 \mathrm{~m}$, there were no consistent seasonal trends in glycogen at $45 \mathrm{~m}$ between the 2 years (Fig. $4 \mathrm{~d}$ ).

Since we measured RNA/DNA and ETS in D. rostriformis bugensis only in 2008, we could only compare the two depths over a seasonal period. RNA/DNA ratios were significantly lower at $45 \mathrm{~m}$ compared to $25 \mathrm{~m}$ (paired $t$-test, $P=0.01 ; n=7$ ). Ratios were lower at $45 \mathrm{~m}$ on each sampling date; overall mean ratios were 1.73 and 1.30 at $25 \mathrm{~m}$ and $45 \mathrm{~m}$, respectively. Distinct seasonal patterns were not apparent except for the greatly lower ratios at both sites in early September

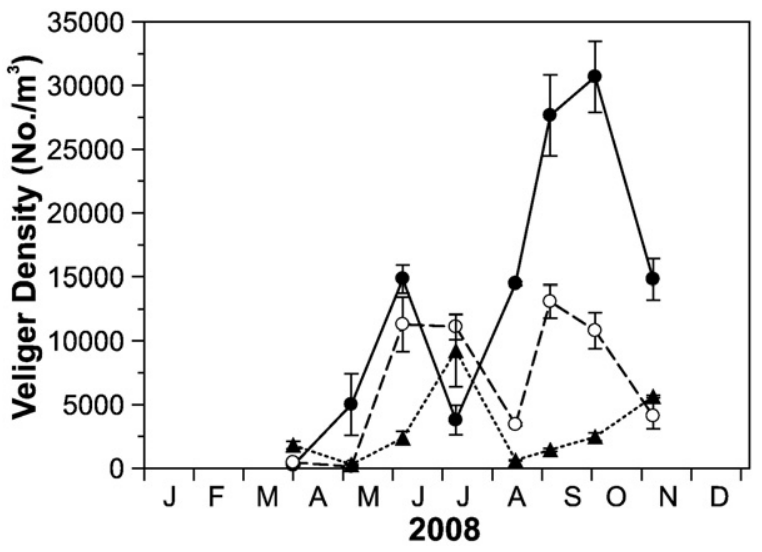

Fig. 7. Mean $( \pm \mathrm{SE})$ density (no. $/ \mathrm{m}^{3}$ ) of Dreissena veligers at $\mathrm{M}-25(25 \mathrm{~m}), \mathrm{M}-45$ $(45 \mathrm{~m})$, and X-2 (93 m) on each sampling date in 2008. M-25 = solid circle/solid line; $\mathrm{M}-45=$ open circle/dashed line; $\mathrm{X}-2=$ solid triangle/dashed line.

(Fig. 5a). In contrast, differences in ETS between the two depths were not significantly different (paired $t$-test, $P=0.51 ; n=8$ ). Values were generally similar at the two sites on each sampling date except in early November (Fig. 5b). On this date, mussels at $45 \mathrm{~m}$ had a mean ETS value that was 2.6 times lower than the mean value at $25 \mathrm{~m}$. Otherwise, seasonal trends were similar at the two sites; values gradually increased from spring to fall. Mean ETS was $105.9 \mu \mathrm{g} \mathrm{O}_{2} / \mathrm{mg}$ $\mathrm{WW} / \mathrm{h}$ at $25 \mathrm{~m}$ and $96.2 \mu \mathrm{g} \mathrm{O}_{2} / \mathrm{mg} \mathrm{WW} / \mathrm{h}$ at $45 \mathrm{~m}$.

Seasonal patterns in water temperature, reproduction, and recruitment of $D$. rostriformis bugensis

Mean bottom temperature at $25 \mathrm{~m}$ (M-25) and $45 \mathrm{~m}$ (M-45) over all sampling dates in 2008 was $10.0^{\circ} \mathrm{C}$ and $5.6^{\circ} \mathrm{C}$, respectively. Bottom temperatures at $25 \mathrm{~m}$ gradually increased in spring, but wide monthto-month fluctuations occurred between July and Sept after thermal stratification (Fig. 6). A maximum temperature of $19.7^{\circ} \mathrm{C}$ occurred in early September. Bottom temperatures were more consistent at $45 \mathrm{~m}$, ranging between $4.4{ }^{\circ} \mathrm{C}$ and $6.2^{\circ} \mathrm{C}$ from early May to October. Maximum temperature at this site was $11.2^{\circ} \mathrm{C}$ in early November. This November sampling date was the only time that bottom temperature at $45 \mathrm{~m}$ exceeded the bottom temperature at $25 \mathrm{~m}$. Bottom temperatures at $93 \mathrm{~m}$ never exceeded $5.0{ }^{\circ} \mathrm{C}$ (Fig. 6).

The analysis of female reproductive state indicated distinctly different seasonal patterns in reproductive development and spawning of $D$. rostriformis bugensis at $25 \mathrm{~m}$ and $45 \mathrm{~m}$ in 2008 (Table 5). At $25 \mathrm{~m}$, all females had mature oocytes on the first sampling date in early April, but these oocytes remained in the gonads through early August. Spent females were first noted in early September, and all females were spent by early November. All females at $45 \mathrm{~m}$ had mature oocytes by late April, but, unlike at $25 \mathrm{~m}$, spent females were soon observed in early June, and all females were spent by early

Table 5

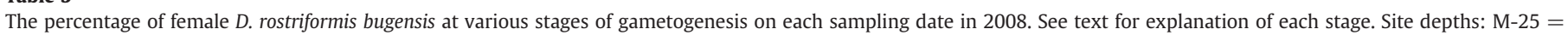
$25 \mathrm{~m}, \mathrm{M}-45=45 \mathrm{~m}$.

\begin{tabular}{|c|c|c|c|c|c|c|c|c|c|c|}
\hline \multirow[t]{2}{*}{ Date/stage } & \multicolumn{5}{|l|}{ M-25 } & \multicolumn{5}{|l|}{ M-45 } \\
\hline & Stage 1 & Stage 2 & Stage 3 & Stage 4 & Stage 5 & Stage 1 & Stage 2 & Stage 3 & Stage 4 & Stage 5 \\
\hline Apr 08 & 0.0 & 0.0 & 0.0 & 100.0 & 0.0 & 0.0 & 16.7 & 41.7 & 41.7 & 0.0 \\
\hline Apr 29 & 0.0 & 0.0 & 0.0 & 100.0 & 0.0 & 0.0 & 0.0 & 0.0 & 100.0 & 0.0 \\
\hline Jun 04 & 0.0 & 0.0 & 0.0 & 100.0 & 0.0 & 0.0 & 0.0 & 0.0 & 40.0 & 60.0 \\
\hline Jul 09 & 0.0 & 0.0 & 0.0 & 100.0 & 0.0 & 0.0 & 0.0 & 0.0 & 40.0 & 60.0 \\
\hline Aug 12 & 0.0 & 0.0 & 0.0 & 100.0 & 0.0 & 0.0 & 0.0 & 0.0 & 0.0 & 100.0 \\
\hline Sep 04 & 0.0 & 0.0 & 0.0 & 80.0 & 20.0 & 0.0 & 0.0 & 0.0 & 0.0 & 100.0 \\
\hline Sep 30 & 0.0 & 0.0 & 0.0 & 60.0 & 40.0 & 0.0 & 0.0 & 0.0 & 0.0 & 100.0 \\
\hline Nov 04 & 50.0 & 0.0 & 0.0 & 0.0 & 50.0 & 70.0 & 0.0 & 0.0 & 0.0 & 30.0 \\
\hline
\end{tabular}




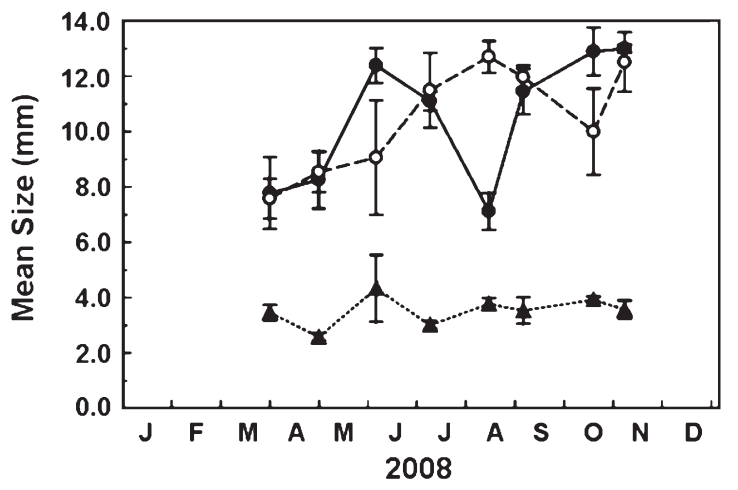

Fig. 8. Mean size ( $\pm \mathrm{SE}$ ) of $D$. rostriformis bugensis at M-25 (25 m), M-45 (45 m), and X$2(93 \mathrm{~m})$ on each sampling date in 2008. M-25 = solid circle/solid line; $\mathrm{M}-45=$ open circle/dashed line; $\mathrm{X}-2=$ solid triangle/dashed line.

August. Thus, spawning at $25 \mathrm{~m}$ occurred after early August and was complete by November, whereas spawning at $45 \mathrm{~m}$ occurred before early June and was complete by early August. As indicated by the percentage of females with early stage oocytes, a new reproductive cycle was initiated at both depths after late September.

Coincident with seasonal spawning patterns at the two depths, veliger densities showed two distinct seasonal peaks, one in spring (early June) and the other in fall (September/October) (Fig. 7). At $25 \mathrm{~m}$, the fall peak was 2 times greater than the spring peak $\left(35,000 / \mathrm{m}^{3}\right.$ vs. $15,000 / \mathrm{m}^{3}$ ), but at $45 \mathrm{~m}$, the fall and spring peaks were similar $\left(12,000 / \mathrm{m}^{3}\right.$ vs. $\left.13,000 / \mathrm{m}^{3}\right)$. Given one spawning event at each site and, since spawning at $25 \mathrm{~m}$ occurred in late summer and spawning at 45 m occurred in spring, the source of the veliger peak at $25 \mathrm{~m}$ in spring was likely from spawned individuals at deeper depths, and the source of the veliger peak at $45 \mathrm{~m}$ in fall was likely from spawned individuals at shallower depths. Veliger densities were also determined at $93 \mathrm{~m}$ (site X-2). Densities at this depth peaked in early July (Fig. 7). Since we did not determine the reproductive state of females at this site, the July peak could have resulted from spawned individuals at the site itself, or from veligers that had been transported offshore from spawned females in shallower regions (i.e., $45 \mathrm{~m}$ ).

Seasonal changes in the relative number of newly settled recruits, as defined by the proportion of individuals $<5 \mathrm{~mm}$, did not closely coincide with spawning and veliger peaks. A relatively high percentage of these small individuals occurred in early spring (April) at both $25 \mathrm{~m}$ (up to 33\%) and $45 \mathrm{~m}$ (50\%), which was before spawning at both depths. Thereafter, the percentage was generally less than $14 \%$ of the population through the rest of the seasonal period. The exception was the high percentage (43\%) at $25 \mathrm{~m}$ in early August. This high percentage was not likely related to reproductive activity since it occurred before spawning at this depth. There was no significant difference in mean size of individuals at 25 and $45 \mathrm{~m}$ (paired $t$-test, $P=0.99 ; n=7$ ). In general, mean size increased from April to November at both depths, with the noted exception of a low mean size at $25 \mathrm{~m}$ in August (Fig. 8). Mean size was lowest in early April $(7.7 \mathrm{~mm})$ and highest in early November $(12.8 \mathrm{~mm})$. Mean size at $93 \mathrm{~m}$ was less than $4 \mathrm{~mm}$ regardless of season; $77-92 \%$ of the population consisted of individuals $<5 \mathrm{~mm}$ over all sampling dates.

\section{Discussion}

D. rostriformis bugensis began to colonize the southern basin of Lake Michigan in 2001 and has progressively expanded from relatively shallow $(<50 \mathrm{~m})$ to deeper $(>50 \mathrm{~m})$ depths ever since. Based on 2008 results, continued population expansion within the former depth region, as indicated by increased density and biomass, was not well defined. At $16-30 \mathrm{~m}$, mean densities continued to increase through 2008, but biomass has not increased since 2004. The population in this depth interval is consistently dominated by small individuals $(<5 \mathrm{~mm})$ that are highly patchy in distribution, perhaps indicating that individuals are settling but not able to grow in this unstable, nearshore habitat. At 31-50 m, mean densities were relatively unchanged between 2006 and 2008, but biomass continued to increase; it was 32\% higher in 2008 compared to 2007. This can be attributed to a maturing population at this depth interval, as mean size was greater in 2008 than in any previous year. Indeed, there was a greater percentage of individuals larger than $15 \mathrm{~mm}$ in 2008 compared to 2007 (24.8\% vs. 16.0\%). Although this percentage increase was relatively minor, these larger individuals accounted for $92 \%$ of the biomass increase at this depth interval between the 2 years. At the very least, these examples emphasize the importance of obtaining biomass in addition to densities when assessing trends over time.

Based on trends in both density and biomass, the population at depths $>50 \mathrm{~m}$ will likely continue to expand. Mean density at 51$90 \mathrm{~m}$ in 2008 was already similar to that found at $31-50 \mathrm{~m}$, although the population only began to expand at this interval in 2005. Biomass at this interval was less than at 31-50 $\mathrm{m}$, but the average size of an individual was much smaller ( $5.1 \mathrm{~mm}$ vs. $9.7 \mathrm{~mm}$ ), indicating that biomass will likely increase at this interval as the population matures. With the average size of an individual even smaller in the $>90-\mathrm{m}$ interval, increases in biomass at this interval may also be expected.

Although dreissenid densities in the Great Lakes have been widely reported, few studies have determined biomass, thus limiting our comparisons. Mean biomass (AFDW) of D. polymorpha on hard substrates in inner Saginaw Bay peaked at $61.9 \mathrm{~g} / \mathrm{m}^{2}$ in 1992 before the population declined (Nalepa et al., 2003). In Lake Erie, mean biomass (tissue DW) of dreissenids was $5.8,14.2$, and $104.7 \mathrm{~g} / \mathrm{m}^{2}$ in the west, central, and eastern basins in 2002 (Patterson et al., 2005). For a more realistic comparison between our Lake Michigan biomass estimates and those in Lake Erie, we restricted the Lake Erie estimates to those found in the deeper region of the eastern basin where the dreissenid population consisted entirely of $D$. rostriformis bugensis, and where environmental conditions (i.e., soft sediments, hypolimnetic temperatures) were most similar to offshore, southern Lake Michigan. Mean biomass (DW) at sites $>24 \mathrm{~m}$ in the eastern basin (maximum depth $64 \mathrm{~m}$ ) was $38.6 \mathrm{~g} / \mathrm{m}^{2}$ (Patterson et al., 2005). At the generally comparable depth of $31-50 \mathrm{~m}$ in Lake Michigan, mean biomass in 2008 was $49.9 \mathrm{~g} / \mathrm{m}^{2}$ (assuming AFDW is $88 \%$ of dry weight as found in this study), which compares well with the eastern basin value.

A recent study in Lake Michigan reported trends in wet weight biomass of dreissenids (shell and soft tissue) at different depth intervals between 1999 and 2007 (Bunnell et al., 2009). In 2007, mean total wet biomass at 9-30 m, 31-60 m, 61-90 m, and 91-110 m was $0.1,4.4,10.3$, and $11.2 \mathrm{~g} / \mathrm{m}^{2}$, respectively. If we convert mean AFDW biomass found in 2007 in our study to whole wet weight, we obtain estimates of $62.7,378.9,92.8$, and $1.0 \mathrm{~g} / \mathrm{m}^{2}$ at our four depth intervals (16-30 m, 31-50 m, 51-90 m, >90 m). Thus, although depth categories were generally similar, our estimates were vastly different from those of Bunnell et al. (2009). These authors collected dreissenids with a fish trawl and recognized that their biomass estimates were biased low. Interestingly, while our wet biomass estimates were 9-300 times higher at the three shallowest intervals, they were 10-fold lower at the deepest interval. We suspect this lower estimate may simply be a result of delayed colonization in the deep region of the southern basin compared to the estimate of Bunnell et al. (2009), which was for the entire lake. In 2008, our total wet biomass at $>90 \mathrm{~m}$ increased to $10.7 \mathrm{~g} / \mathrm{m}^{2}$, a value more comparable. Regardless, it seems apparent that while trawl collections may be useful in determining relative abundances of the various dreissenid species, or shifts in spatial distributions (Mills et al., 1999; French et al., 2007; Bunnell et al., 2009), they should not be relied upon to estimate population density or biomass. 
The gradual expansion of $D$. rostriformis bugensis into offshore regions as found in southern Lake Michigan is not unique to the Great Lakes; similar expansions have been documented in Lake Ontario (Watkins et al., 2007) and in Lake Huron (French et al., 2009). However, the D. rostriformis bugensis population in southern Lake Michigan seems to be increasing at a comparatively rapid rate. For example, D. rostriformis bugensis was first found in Lake Ontario in the early 1990s and has been expanding ever since (Mills et al., 1993, 1999; Watkins et al., 2007). In the most recent survey conducted in 2003, which was about 10 years after the population became established, mean density was $8106 / \mathrm{m}^{2}$ at $31-90 \mathrm{~m}$ (Watkins et al., 2007). Mean density in southern Lake Michigan at 31-90 $\mathrm{m}$ in 2008 was $13,800 / \mathrm{m}^{2}$ after just 7 years. Further, D. rostriformis bugensis became established in Lake Huron at the same time as in Lake Michigan (Nalepa et al., 2001), but mean density at 31-90 m in 2007 was only $1173 / \mathrm{m}^{2}$ (Nalepa, unpublished data).

The decline and virtual disappearance of $D$. polymorpha as $D$. rostriformis bugensis expanded in the southern basin follows a pattern reported previously throughout Lake Michigan (Nalepa et al., 2009) and in other Great Lakes (Mills et al., 1999; Patterson et al., 2005; Wilson et al., 2006). Laboratory experiments have shown that, compared to $D$. polymorpha, D. rostriformis bugensis has a lower respiration rate at various seasonal temperatures (Stoeckmann, 2003) and a higher assimilation efficiency, especially at low food concentrations (Baldwin et al., 2002). These attributes allow D. rostriformis bugensis to allocate less energy to metabolic maintenance and more to growth and reproduction. The two most consistent differences between the two species in our study was the amount of tissue mass within the shell cavity $(\mathrm{CI})$, and the shell weight per unit shell length (SW/SL). Overall, mean CI for D. rostriformis bugensis was $27 \%$ higher, and mean SW/SL was $48 \%$ lower relative to D. polymorpha. These differences suggest that, under exactly the same environmental conditions, D .r. bugensis allocates greater amounts of energy to tissue mass relative to shell mass. With tissue loss a common occurrence in dreissenids subjected to nutritional stress (Sprung and Borcherding, 1991), D. rostriformis bugensis would be better suited to survive under low food conditions.

The nutritional state of $D$. polymorpha in 2004 was generally similar to values found in other regions of the Great Lakes where populations were in the state of decline. The most commonly used indicator of dreissenid condition in the Great Lakes has been the tissue weight-shell length relationship (Nalepa et al., 1993, 1995; Chase and Bailey, 1999a; Vanderploeg et al., 2009). Based on the four sites sampled in 2004, tissue weight of a standard $15-\mathrm{mm}$ D. polymorpha in fall was $6.2 \mathrm{mg}$ (range $5.1-7.2 \mathrm{mg}$ ). Fall is considered the best time to assess this indicator since spawning has occurred, and values more realistically reflect baseline tissue weight. When populations peaked and were declining in Saginaw Bay, a $15-\mathrm{mm}$ individual weighed $3.1 \mathrm{mg}$ (Nalepa et al., 1995), and in Lake St. Clair, the weight of a 15$\mathrm{mm}$ individual within a declining population was 5.8-9.1 $\mathrm{mg}$ (Nalepa et al., 1993). For perspective, tissue weight of a $15-\mathrm{mm} D$. polymorpha is generally over $8 \mathrm{mg}$ when food is not limiting (Nalepa et al., 1995).

Although numerous factors can influence size structure of dreissenid populations including growth, reproduction, and sizespecific predation, trends in size structure relative to density can provide insights into the mechanisms for population shifts. In general, during the early stages of dreissenid colonization, the population is dominated by small individuals, but over time, mean size increases as the population matures and several year-classes become present (Nalepa et al., 1995). Food requirements per unit of tissue mass increases with size of the individual (Walz 1978a,b; Wacker and von Elert, 2008), so an increasing mean size after initial colonization suggests adequate food resources. Conversely, a decreasing mean size suggests limited food availability. Mean size of $D$. polymorpha declined along with density as chlorophyll levels declined in Lake St. Clair (Nalepa et al., 1996). Also, mean size of D. rostriformis bugensis increased, and that of $D$. polymorpha declined, as the former species replaced the latter in Lake Erie (Mills et al., 1999). Since size structure at $16-30 \mathrm{~m}$ was highly variable from year-to-year and likely influenced by physical disturbances (wave action, unstable substrates), the 31- to 50-m interval was better suited to examine trends in size structure relative to density. For D. polymorpha, there was a good correlation between mean size and density (Pearson correlation coefficient $=0.71$ ) over the period 1998-2005 when this species was still present. Along with density, mean shell length increased to a peak in 2001-2002 and then declined. Increasing mean size would indicate that the population was still growing at a good rate at the time $D$. rostriformis bugensis began to colonize this depth interval in 20012002. Filtering capacity of the dreissenid population at this depth interval in 2001-2002 was still below algal growth rates suggesting adequate food resources (Vanderploeg et al., 2010). A decline in mean size along with decreased densities after 2001-2002 suggests that larger individuals were disappearing from the population, consistent with decreased food availability. For D. rostriformis bugensis, mean size and density were not as well correlated (Pearson correlation coefficient $=0.51$ ) over the period 2002-2008, suggesting slow growth rates relative to increased density. During this 6-year period, the increase in mean size of the $D$. rostriformis bugensis population at 31-50 m was only $0.6 \mathrm{~mm} /$ year. In comparison, mean size of the $D$. polymorpha population between 1998 and 2001 at the same depth interval was $1.9 \mathrm{~mm} /$ year. During the early colonization period between 1992 and 1995 in a shallow region of eastern Lake Erie $(<30 \mathrm{~m})$, mean size of $D$. rostriformis bugensis increased $1.3 \mathrm{~mm} /$ year (Mills et al., 1999). Although growth rates at 31-50 m were relatively low, mean size of the population was still increasing in 2008, seemingly indicating that the population was not yet food limited.

Depths of the two sites where dreissenids were collected for documenting seasonal reproductive activity and nutritional state ( $25 \mathrm{~m}$ and $45 \mathrm{~m}$ ) were specifically located above and below the thermocline to examine the influence of different temperature regimes. Temperature has a strong, direct influence on seasonal reproductive activity in D. polymorpha (Sprung, 1987; Nichols, 1996), but little is known of temperature impacts on reproductive activity in $D$. rostriformis bugensis. The seasonal timing of gametogenesis and spawning in $D$. rostriformis bugensis at the two depths was indeed different, but trends relative to temperature varied from what we expected. At $45 \mathrm{~m}$, all females had mature oocytes in late April and spawning began soon after when bottom temperatures were at 4.5$6.0^{\circ} \mathrm{C}$. These findings agree with others that show spawning of $D$. rostriformis bugensis occurs in spring in deeper regions. For instance, Claxton and Mackie (1998) found that D. rostriformis bugensis profunda spawned in late June at $23 \mathrm{~m}$ when temperatures reached $9{ }^{\circ} \mathrm{C}$ in eastern Lake Erie, and Roe and MacIsaac (1997) collected spawned and gravid (with mature oocytes) females in mid-July (their only sampling date) at $37 \mathrm{~m}$ and $55 \mathrm{~m}$ when water temperatures were 4.8-6. ${ }^{\circ} \mathrm{C}$. Although the change was minor, potentially the temperature increase at our $45-\mathrm{m}$ site from a winter low of $2{ }^{\circ} \mathrm{C}$ to $4.5-6.0{ }^{\circ} \mathrm{C}$ could have triggered spawning. In contrast, spawning at $25 \mathrm{~m}$ did not occur until late summer despite females having mature oocytes since early April. Temperature warmed first at $25 \mathrm{~m}$, thus, if an increase in temperature initiated spawning, we should have observed spawning first at this depth. Either absolute increases in temperature had little impact as a spawning trigger, or other environmental cues were more important. Ram and Nichols (1993) argued that an increase in temperature may provide favorable conditions to spawn, but does not trigger it. Rather, chemicals associated with phytoplankton are the key triggering mechanism. As argued, temperatures can vary erratically, while phytoplankton increases are generally gradual and integrate environmental conditions (including temperature) that favor successful mussel recruitment. It is difficult to offer a scenario where phytoplankton cues were present earlier at $45 \mathrm{~m}$ compared to $25 \mathrm{~m}$, but bottom temperatures at $25 \mathrm{~m}$ fluctuated broadly and 
conceivably may have delayed spawning relative to $45 \mathrm{~m}$. Temperature stability can have a strong impact on spawning (Ram and Nichols, 1993). Regardless, it is apparent that environmental cues that trigger spawning at these depths in Lake Michigan need further investigation.

Based on the evidence, reproductive effort was greater at $25 \mathrm{~m}$ than at $45 \mathrm{~m}$. The amount of reproductive material can be estimated from the change in tissue mass before and after spawning (Nalepa et al., 1993; Chase and Bailey, 1999b). Since Claxton and Mackie (1998) found that individuals of $D$. rostriformis bugensis greater than $8 \mathrm{~mm}$ were mature and capable of spawning, we assume that all individuals in our study for which we measured nutritional state and biochemical content (smallest size $=9 \mathrm{~mm}$ ) were also capable of spawning. In 2008 , tissue dry mass as measured by CI declined by $41 \%$ after spawning at $25 \mathrm{~m}$, compared to a decline of $26 \%$ at $45 \mathrm{~m}$. Postspawning declines in AFDW/SL and lipid content were also greater at $25 \mathrm{~m}$. Overall, percentage declines in tissue mass are within the range of $20-45 \%$ for D. polymorpha in shallower waters (Sprung and Borcherding, 1991; Sprung, 1995), and also the 20-40\% decline observed in a number of marine mussel species that have a pelagic life stage (summarized in Sprung, 1995). The greater reproductive effort at $25 \mathrm{~m}$ was evident when the peak in the number of postspawn veligers was determined on an areal basis and examined relative to benthic adult biomass. Veliger numbers peaked at $336,500 / \mathrm{g}$ AFDW at $25 \mathrm{~m}$ compared to $13,300 / \mathrm{g}$ AFDW at $45 \mathrm{~m}$.

The seasonal timing of spawning at the two depths varied (i.e., late summer at $25 \mathrm{~m}$, spring at $45 \mathrm{~m}$ ), and although peaks in veliger densities coincided with spawning at both depths, spawning at one depth also led to increased veliger densities at the other. This suggests considerable horizontal mixing of veligers across depth regions. In large lakes, hydrodynamic forces such as longshore currents and upwelling/downwelling are an effective mechanism by which veligers get transported from nearshore to offshore and also from offshore to nearshore (Wacker and von Elert, 2003). There has been some uncertainty as to whether $D$. rostriformis bugensis recruits in deeper regions originated from local adults, or originated from adults in shallower regions and were transported offshore (Roe and Maclsaac, 1997; Martel et al., 2001). The spring spawning at $45 \mathrm{~m}$ and the subsequent increase in veligers at both $45 \mathrm{~m}$ and $25 \mathrm{~m}$ suggests that adults found in deeper waters contribute not only to local recruitment but also to recruitment in shallower water.

A clear increase in new recruits relative to seasonal reproductive events was not apparent. The greatest proportion of individuals $<5 \mathrm{~mm}$ occurred in early spring at both sites in 2008 , suggesting that these spring recruits were the previous year's cohort that had settled over winter. Recruitment can be highly variable in dreissenids and may not necessarily be synchronous with spawning activity or related to veliger abundances (Sprung, 1989; Chase and Bailey, 1999a; Wacker and von Elert, 2003).

Based on differences in the various indices of condition, the nutritional state of $D$. rostriformis bugensis was lower at $45 \mathrm{~m}$ than at $25 \mathrm{~m}$ for the Muskegon sites. That is, CI, AFDW/SL, and lipid content were lower at $45 \mathrm{~m}$ in both 2004 and 2008, and growth, as measured by RNA/DNA in 2008, was also lower. Seemingly inconsistent with these results, however, were the higher values of some indices at $45 \mathrm{~m}$ compared to $20 \mathrm{~m}$ off Waukegan in 2004. We suspect this different spatial pattern was a function of relatively low dreissenid densities and hence higher food availability at the Waukegan 45-m site. In 2004 , total dreissenid density at this site was only $600 / \mathrm{m}^{2}$ compared to $9700 / \mathrm{m}^{2}$ at the $45-\mathrm{m}$ site off Muskegon. In 2008, mean density at the former site increased to $9060 / \mathrm{m}^{2}$; unfortunately, nutritional state was not measured at the Waukegan sites in 2008.

Lower nutritional state of $D$. rostriformis bugensis at $45 \mathrm{~m}$ compared to $25 \mathrm{~m}$ was likely a function of lower food availability at the former depth. Mean chlorophyll in 2008 at $45 \mathrm{~m}$ was $1.3 \mu \mathrm{g} / \mathrm{L}$ compared to $2.5 \mu \mathrm{g} / \mathrm{L}$ at shallower depths (Vanderploeg et al.,
2010). Further, biomass was consistently greater at $31-50 \mathrm{~m}$ compared to $16-30 \mathrm{~m}$ (Fig. 3), leading to greater competition for food resources. Greater biomass at the former interval despite lower food availability can best be explained by physical features of the nearshore/offshore environment in this region of Lake Michigan. Before dreissenid colonization, biomass of the benthic community was greater at $31-50 \mathrm{~m}$, and this spatial pattern was attributed to unstable bottom conditions at shallower depths (Mozley and Winnell, 1975; Nalepa, 1989). Above the thermocline, wave-induced sediment resuspension and temperature fluctuations create a harsh environment for benthic populations and limit numbers. We suspect these same physical features were limiting D. rostriformis bugensis populations at our $25-\mathrm{m}$ site. These features would affect population size through diminished survival, but have minimal impact on nutritional state; that is, mussels that survive these harsh conditions would likely not be food limited.

Given high standing stocks at 31-50 m, does the nutritional state of $D$. rostriformis bugensis at $45 \mathrm{~m}$ indicate that the population is nearing self-limitation? The various indices provided a mixed interpretation. Both indices based on tissue mass, CI and AFDW/SL, were lower in 2008 compared to 2004, but lipid content was little changed between years, and glycogen was higher. The increase in 2008 for glycogen was a result of atypically low values found in 2004, which did not vary with season or depth as found in 2008. In laboratory experiments with $D$. polymorpha, glycogen levels did not decline over a period of starvation as did lipid content and tissue weight (Frischer et al., 2000), suggesting glycogen content may not be a good indicator of nutritional stress in D. rostriformis bugensis. Comparisons of studies assessing the relationship between food availability and nutritional response in D. polymorpha showed that both lipids and carbohydrates are more variable and inconsistent relative to tissue mass as indicators of nutritional stress (Nalepa et al., 1993). The tissue weight of a $15-\mathrm{mm}$ D. rostriformis bugensis at $45 \mathrm{~m}$ in 2008 was $5.7 \mathrm{mg}$, a value below the $8.1 \mathrm{mg}$ and $12.1 \mathrm{mg}$ found for a 15-mm D. rostriformis bugensis at $37 \mathrm{~m}$ and $55 \mathrm{~m}$ in eastern Lake Erie (Roe and MacIsaac, 1997), and comparable to the $5.2 \mathrm{mg}$ value found for a $15-\mathrm{mm} D$. polymorpha at this depth in 2004. Thus, based on changes in relative tissue mass, $D$. rostriformis bugensis may indeed be nutritionally stressed. Since $D$. rostriformis bugensis began to expand in this region of Lake Michigan, spring chlorophyll levels declined from over $4 \mu \mathrm{g} / \mathrm{L}$ to near $1 \mu \mathrm{g} / \mathrm{L}$ in offshore waters, and the spring diatom bloom is no longer evident (Fahnenstiel et al., 2010). Diatoms are a rich food source, and isothermal mixing in the spring gives bottom-dwelling dreissenids access to diatoms throughout the entire water column. Despite the relatively low nutritional state of the individual based on tissue mass, the population in 2008 was still in a state of expansion as indicated by the continued increase in population biomass and mean size. Seemingly, there is a different feedback mechanism between nutritional state of the individual and population growth for $D$. rostriformis bugensis as compared to D. polymorpha, which may be expected given its higher assimilation efficiency and lower respiration rate (Baldwin et al., 2002; Stoeckmann, 2003).

Spatial and seasonal differences in the RNA/DNA ratio and ETS are difficult to interpret because these variables have not been well studied in dreissenids. While the amount of DNA is fixed within a cell, the amount of RNA is a function of somatic growth, and the ratio will vary depending on such factors as food availability, temperature, and life stage (Chicharo and Chicharo, 2008). The ratio was greater at $25 \mathrm{~m}$ compared to $45 \mathrm{~m}$, indicating growth was greater at $25 \mathrm{~m}$, which is consistent with other indices indicating nutritional state was better at the shallower depth. The ratio varied little over a seasonal period, except for the unexplained large decline at both sites in early September. Growth in dreissenids declines during the spawning period (Sprung, 1995). However, while the September decline occurred during the time of spawning at $25 \mathrm{~m}$, it did not occur at 
the time of spawning at $45 \mathrm{~m}$. The otherwise seasonally stable ratio at both depths suggests that growth is consistent throughout the year and uninfluenced by seasonal changes in temperature or reproductive activity. While both temperature and food availability can influence dreissenid growth (Walz 1978a,b; Sprung, 1995; MacIsaac, 1994; Wacker and von Elert, 2008), the lack of seasonal changes in the ratio at both depths suggests that the lower ratio at $45 \mathrm{~m}$ was a result of lower food availability rather than lower temperatures compared to $25 \mathrm{~m}$. Excluding the atypical values in early September, the mean RNA/DNA ratio for D. rostriformis bugensis was 1.9 and 1.4 at 25 and $45 \mathrm{~m}$, respectively. Without controlled experiments to assess changes in ratios relative to food conditions, the relevance of these low values is not clear. In many organisms, values $<1$ suggest nutritional stress and diminished survival (Chicharo and Chicharo, 2008). In laboratory experiments, Schlechtriem et al. (2008) examined the RNA/DNA ratios in starving Mysis and found values $<1.5-1.8$ were indicative of metabolically stressed animals; ratios of in situ animals were generally greater than 2 . If anything, relatively low ratios in $D$. rostriformis bugensis would suggest that growth was minimal, consistent with the slow growth rate of the population based on size structure as discussed previously.

The assay for ETS activity estimates the potential respiratory capacity of the organism by measuring the enzymatic activity of the rate-limiting step in oxygen utilization for adenosine triphosphate (ATP) production. For ETS, this step is the oxidation of the coenzyme UQ-cytochrome $b$ complex (Broberg, 1985). The assay has been widely used to measure the oxygen consumption potential of seawater, sediments, phytoplankton, and zooplankton (Packard, 1971; Packard et al., 1971; Jones and Simon, 1979). Since an organism's ETS activity requires several days to weeks to adjust to changes in environmental conditions, it is less subject to experimental artifacts and short-term fluctuations when compared to direct measurements of respiration (Bämstedt, 1980; Cammen et al., 1990).

Similar to the RNA/DNA ratio, seasonal changes in ETS were not related to reproductive activity at either $25 \mathrm{~m}$ or $45 \mathrm{~m}$. Rather, the gradual increase in ETS from spring to fall at both depths suggests that temperature was the driving variable for this seasonal pattern. In dreissenids, there is a strong relationship between ETS/respiration and water temperature (Fanslow et al., 2001; Stoeckmann, 2003). Yet ETS at $25 \mathrm{~m}$ and $45 \mathrm{~m}$ was similar, despite the generally higher temperatures at $25 \mathrm{~m}$. Short-term, temperature fluctuations were far greater at $25 \mathrm{~m}$ compared to $45 \mathrm{~m}$ and, since ETS is a long-term metabolic response to environmental conditions, these short-term fluctuations may have had a negative influence on ETS. ETS was actually greater at $45 \mathrm{~m}$ during the stratified period (July-September) when temperature fluctuations at $25 \mathrm{~m}$ were most severe. Similarly, the dramatic, one-time decline in ETS at $45 \mathrm{~m}$ occurred in November when temperatures were twice that found on any other sampling date. Interestingly, the RNA/DNA ratio (i.e., growth) did not increase with seasonal temperature increases while ETS (i.e., respiration) did. Hence, it seems that $D$. rostriformis bugensis can regulate food intake or assimilation efficiency to maintain growth in lieu of higher metabolic costs. Assimilation efficiency in D. rostriformis bugensis can be highly variable (Baldwin et al., 2002).

ETS for D. rostriformis bugensis in southern Lake Michigan was 2-3 times less than for $D$. polymorpha in outer Saginaw Bay at similar temperatures. Over the entire seasonal period in Lake Michigan, mean ETS was $7.94 \mu \mathrm{g} \mathrm{O}_{2} / \mathrm{mg} \mathrm{DW} / \mathrm{h}(\mathrm{DW}=7.1 \% \mathrm{WW})$ and mean temperature was $10.0^{\circ} \mathrm{C}$ at $25 \mathrm{~m}$, while mean ETS was $3.94 \mu \mathrm{g}$ $\mathrm{O}_{2} / \mathrm{mg} \mathrm{DW} / \mathrm{h}(\mathrm{DW}=4.1 \% \mathrm{WW})$ and mean temperature was $5.6{ }^{\circ} \mathrm{C}$ at $45 \mathrm{~m}$. From an ETS/temperature regression derived from two seasonal periods in outer Saginaw Bay (Fanslow et al., 2001), comparable ETS values for $D$. polymorpha were $15.1 \mu \mathrm{g} \mathrm{O}_{2} / \mathrm{mg} \mathrm{DW} / \mathrm{h}$ at $10.0{ }^{\circ} \mathrm{C}$ and $9.6 \mu \mathrm{g} \mathrm{O}_{2} / \mathrm{mg} \mathrm{DW} / \mathrm{h}$ at $5.6{ }^{\circ} \mathrm{C}$. Although we did not measure respiration $(R)$ directly, it can be approximated from the relationship between ETS and $R$, which is generally consistent for a given taxonomic group and a function of life mode, with more active organisms having higher ratios (Cammen et al., 1990). For D. polymorpha in Saginaw Bay, the ratio varied between 0.02 and 0.09 over a seasonal period (Fanslow et al., 2001), and in laboratory experiments, the ratio for $D$. polymorpha was $0.06-0.07$ regardless of individual size (Madon et al., 1998). Since both $D$. rostriformis bugensis and $D$. polymorpha have a similar sessile life mode, we assume a comparable ETS $/ R$ ratio of 0.06 for $D$. rostriformis bugensis. From this ratio, mean respiration rates were estimated to be $0.48 \mu \mathrm{g} \mathrm{O}_{2} / \mathrm{mg}$ $\mathrm{DW} / \mathrm{h}$ and $0.23 \mu \mathrm{g} \mathrm{O}_{2} / \mathrm{mg} \mathrm{DW} / \mathrm{h}$ at $25 \mathrm{~m}$ and $45 \mathrm{~m}$, respectively. These values are far less than the $1.45 \mu \mathrm{g} \mathrm{O}_{2} / \mathrm{mg} \mathrm{DW} / \mathrm{h}$ and $0.95 \mu \mathrm{g}$ $\mathrm{O}_{2} / \mathrm{mg} \mathrm{DW} / \mathrm{h}$ at comparable temperatures $\left(10.0{ }^{\circ} \mathrm{C}\right.$ and $5.0^{\circ} \mathrm{C}$ ) reported for $D$. rostriformis bugensis from Lake Erie (Stoeckmann, 2003). The phenotype of $D$. rostriformis bugensis in the Lake Erie study was not given but was likely the eplimnetic phenotype since the mussels were collected from a depth of only $4-5 \mathrm{~m}$ in the shallow western basin. Our lower estimates of respiration rates for the profunda phenotype suggest that this phenotype has lower metabolic costs and is thus better suited to the low food availability found in offshore waters compared to the eplimnetic phenotype. Also, it suggests that the profunda phenotype will more effectively outcompete $D$. polymorpha and potentially explains its rapid displacement of D. polymorpha in southern Lake Michigan.

As discussed by Nalepa et al. (2009), the expansion of $D$. rostriformis bugensis in southern Lake Michigan represents a major increase in benthic biomass and a disruption in the flow of nutrients/energy through the food web. Mean biomass (AFDW) of the benthic community in the southern basin before dreissenid introduction (i.e., 1980 and 1981) was $4.9,7.8,4.2$, and $1.9 \mathrm{~g} / \mathrm{m}^{2}$ at $16-30 \mathrm{~m}, 31-50 \mathrm{~m}, 51-90 \mathrm{~m}$, and $>90 \mathrm{~m}$ (Nalepa, 1989). When weighted for depth over the entire basin, total mean benthic biomass in the early 1980 s was $4.0 \mathrm{~g} / \mathrm{m}^{2}$. In 2008 , depth-weighted biomass of just $D$. rostriformis bugensis was $10.9 \mathrm{~g} /$ $\mathrm{m}^{2}$, over a 2.5 -fold increase. With nutrient loads declining in Lake Michigan between the early 1980s and 2008 (Mida et al., 2010), carrying capacity for biological productivity in the lake has declined, and therefore, the increase in benthic biomass must have come at a cost to other components of the food web. For one, the benthic amphipod Diporeia has been steadily declining in Lake Michigan since the introduction of dreissenids (Nalepa et al., 2009). Depth-weighted biomass of Diporeia in $1980-1981$ was $2.5 \mathrm{~g} / \mathrm{m}^{2}$, so even the near complete loss of Diporeia from the southern basin can only account for a portion (36\%) of the mass now represented in D. rostriformis bugensis standing stocks. Further, the increase in benthic biomass does not take into account dreissenid shell mass. Shells take energy to produce but have no energetic value to other trophic levels. Shell material accounted for 91\% of dry mass of $D$. rostriformis bugensis in 2008 (all dates at both sites), so total depth-weighted mean standing stock of just shell material in the southern basin was $121 \mathrm{~g} / \mathrm{m}^{2}$. This represents energy totally lost to the food web at any given point in time.

Some fish species feed on dreissenids and may derive some benefits (Pothoven and Nalepa 2006; Madenjian et al. 2010), but direct and indirect negative impacts of dreissenids on fish have been widely reported (Mohr and Nalepa 2005; Hondorp et al., 2005; Madenjian et al., 2006). Coincident with the expansion of $D$. rostriformis bugensis, prey fish biomass in Lake Michigan declined 71\% between 2003 and 2007 (Bunnell et al., 2009) and may represent a majority of the remaining energetic trade-off for the increase in $D$. rostriformis bugensis standing stocks. While it was argued that the decrease in prey fish biomass was more coincidental than mechanistic relative to the expansion of $D$. rostriformis bugensis (Bunnell et al., 2009), continued examination of trends will provide further insights into direct and indirect relationships between $D . r$ bugensis and fish populations. As of 2008 , the $D$. rostriformis bugensis population at depths $<50 \mathrm{~m}$ in southern Lake Michigan was becoming more stable but not decreasing, while the population at $>50 \mathrm{~m}$ was still expanding. The population at the latter depth interval was dominated by small 
individuals. While conceivably these individuals may be somewhat food-limited because of recent decreases in pelagic productivity in the offshore (Fahnenstiel et al., 2010), we suspect that future increases in biomass will occur as the population matures, and continued impacts on other food web components can be expected.

\section{Acknowledgments}

We thank the crews of the $R / V$ Shenehon, $R / V$ Laurentian, and $R / V$ Lake Guardian for their support and assistance during field operations; the Great Lakes National Program Office, US EPA, for use of the Lake Guardian; the many outstanding research assistants that helped to collect samples and count organisms during the many years of this study. We thank more recent assistants Tom Apelbacher, Katie Birkett, Laurie Cummins, Andrew Foley, III, Derek Lamarand, and Kerrin Mabrey for processing the samples, and Max Jin, Robert Pan, and Margaret Wu for measuring all the mussels. This is GLERL contribution no. 1543.

\section{References}

Austin, H., Haven, D.D., Moustafa, M.S., 1993. The relationship between trends in a condition index of the American oyster, Crassostrea virginica, and environmental parameters in three Virginia estuaries. Estuaries 16, 362-374.

Baldwin, B.S., Mayer, M.S., Dayton, J., Pau, N., Mendilla, J., Sullivan, M., Moore, A., Ma, M., Mills, E.L., 2002. Comparative growth and feeding in zebra and quagga mussels (Dreissena polymorpha and Dreissena bugensis); implications for North American lakes. Can. J. Fish. Aquat. Sci. 59, 680-694.

Bämstedt, U., 1980. ETS activity as an estimator of respiratory rate of zooplankton populations. The significance of variations in environmental factors. J. Exp. Mar. Biol. Ecol. 42, 267-283.

Bämstedt, U., 2000. A new method to estimate respiration rate of biological material based on the reduction of tetrazolium violet. J. Exp. Mar. Biol. Ecol. 251, 239-263.

Broberg, A., 1985. A modified method for studies of electron transport system activity in freshwater sediments. Hydrobiologia 120, 181-187.

Bunnell, D.B., Madenjian, C.P., Holuszko, J.D., Adams, J.V., French III, J.R.P., 2009. Expansion of Dreissena into offshore waters of Lake Michigan and potential impacts on fish populations. J. Great Lakes Res. 35, 74-80.

Cammen, L.M., Corwin, S., Christensen, J.P., 1990. Electron transport system (ETS) activity as a measure of benthic macrofaunal metabolism. Mar. Ecol. Prog. Ser. 65, 171-182.

Chase, M.E., Bailey, R.C., 1999a. The ecology of the zebra mussel (Dreissena polymorpha) in the lower Great Lake of North America: I. population dynamics and growth. J Great Lakes Res 25, 107-121.

Chase, M.E., Bailey, R.C., 1999b. The ecology of the zebra mussel (Dreissena polymorpha) in the lower Great Lake of North America: II. Total production, energy allocation, and reproductive effort. J. Great Lakes Res. 25, 1122-1134.

Chicharo, M.A., Chicharo, L., 2008. RNA:DNA ratio and other nucleic acid derived indices in marine ecology. Int. J. Mol. Sci. 9, 1453-1471.

Claxton, W.T., Mackie, G.L., 1998. Seasonal and depth variations in gametogenesis and spawning of Dreissena polymorpha and Dreissena bugensis in eastern Lake Erie. Can. J. Zool. 76, 2010-2019.

Crosby, M.P., Gale, L.D., 1990. A review and evaluation of bivalve condition methodologies with a suggested standard method. J. Shellfish Res. 9, 233-237.

Dermott, R., Munawar, M., 1993. Invasion of Lake Erie offshore sediments by Dreissena and its ecological implications. Can. J. Fish. Aquat. Sci. 50, 2298-2304.

Diggins, T.P., 2001. A seasonal comparison of suspended sediment filtration by quagga (Driessena bugensis) and zebra (D. polymorpha) mussels. J. Great Lakes Res. 27, 457-466.

Fahnenstiel, G., Pothoven, S., Nalepa, T., Vanderploeg, H.A., Klarer, D., Scavia, D., 2010. Recent changes in primary production and phytoplankton in the offshore region of southeastern Lake Michigan. J. Great Lakes Res. 36 (Supplement 3), 20-29.

Fanslow, D.L., Nalepa, T.F., Johengen, T.H., 2001. Seasonal changes in the respiratory electron transport system (ETS) and respiration of the zebra mussel, Dreissena polymorpha in Saginaw Bay, Lake Huron. Hydrobiologia 448, 61-70.

Folch, J., Lees, M., Stanley, Sloane G.H., 1956. A simple method for the isolation and purification of total lipids from animal tissues. J. Biol. Chem. 226, 497-509.

French III, J.R.P., Adams, J.V., Craig, J., Stickel, R.G., Nichols, S.J., Fleischer, G.W., 2007. Shell-free biomass and population dynamics of dreissenids in offshore Lake Michigan, 2001-2003. J. Great Lakes Res. 33, 536-545.

French III, J.R.P., Schaeffer, J.S., Roseman, E.F., Kiley, C.S., Fouilleroux, A., 2009. Abundance and distribution of benthic invertebrates in offshore soft sediments in Western Lake Huron, 2001-2007. J. Great Lakes Res. 35, 120-127.

Frischer, M.E., Nierzwicki-Bauer, S.A., Parsons, R.H., Vathanodorn, K., Waitkus, K.R., 2000. Interactions between zebra mussels (Dreissena polymorpha) and microbial communities. Can. J. Fish. Aquat. Sci. 57, 591-599.

Gardner, W.S., Frez, W.A., Cichocki, E.A., 1985. Micromethod for lipids in aquatic invertebrates. Limnol. Oceanogr. 30, 1099-1105.
Gorokhova, E., Kyle, M., 2002. Analysis of nucleic acids in Daphnia: development of methods and ecosystem engineers: the role of shell production in aquatic habitats. Oikos 101, 79-90.

Hecky, R.E., Smith, R.E.H., Barton, D.R., Guildford, S.J., Taylor, W.D., Charlton, M.N Howell, T., 2004. The nearshore phosphorus shunt: a consequence of ecosystem engineering by dreissenids in the Laurentian Great Lakes. Can. J. Fish. Aquat. Sci. 61, 1285-1293.

Hondorp, D.W., Pothoven, S.A., Brandt, S.B., 2005. Influence of Diporeia density on the diet of planktivorous fishes in southeast Lake Michigan. Trans. Amer. Fish. Soc. 134, 588-601.

Hook, T., Gorokhova, E., Hansson, S., 2008. RNA:DNA ratios of Baltic Sea herring larvae and copepods in embayment and open sea habitats. Estuar. Coast. Shelf Sci. 76, 29-35.

Jones, J.G., Simon, B.M., 1979. The measurement of electron transport system activity in freshwater benthic and planktonic samples. J. Appl. Bacter. 46, 305-315.

MacIsaac, H.J., 1994. Comparative growth and survival of Dreissena polymorpha and Dreissena bugensis, exotic molluscs introduced to the Great Lakes. J. Great Lakes Res. 20, 784-790.

Madenjian, C.P., Pothoven, S.A., Dettmers, J.M., Holuszko, J.D., 2006. Changes in seasonal energy dynamics of alewife (Alosa pseudoharengus) in Lake Michigan after invasion by dreissenid mussels. Can. J. Fish. Aquat. Sci. 63, 891-902.

Madenjian, C.P., Pothoven, S.A., Scheeburger, P.J., Ebener, M.P., Mohr, L.C., Nalepa, T.F, Bence, J.R., 2010. Dreissenid mussels are not a "dead end" in Great Lakes food webs. J. Great Lakes Res. 36 (Supplement 1), 73-77.

Madon, S.P., Schneider, D.W., Stoeckel, J.A., 1998. In situ estimation of zebra musse metabolic rates using the electron transport system (ETS) assay. J. Shellfish. Res. 17, 195-203.

Marsden, J.E., Trudeau, N., Keniry, T., 1993. Zebra mussel study of Lake Michigan. Aquat. Ecol. Tech. Rept., 93/14. Illinois Natural History Survey.

Martel, A.L., Baldwin, B.S., Dermott, R.M., Lutz, R.A., 2001. Species and epilimnion/ hypolimnion-related differences in size at larval settlement and metamorphosis in Dreissena (Bivalvia). Limnol. Oceanogr. 46, 707-713.

Mercado-Silva, N., 2005. Condition index of the eastern oyster, Crassostrea virginica (Gmelin, 1791) in Sapelo Island Georgia -effects of site, position on bed, and pea crab parasitism. J. Shellfish Res. 24, 121-126.

Mida, J.L., Scavia, D., Fahnenstiel, G.L., Pothoven, S.A., Vanderploeg, H.A., Dolan, D.M., 2010. Long-term and recent changes in southern Lake Michigan water quality with implications for present trophic status. J. Great Lakes Res. 36 (Supplement 3), 42-49.

Mills, E.L., Dermott, R.M., Roseman, E.F., Dustin, D., Mellina, E., Conn, D.B., Spidle, A.P. 1993. Colonization, ecology, and population structure of the "quagga" mussel (Bivalvia:Dreissenidae) in the lower Great Lakes. Can. J. Fish. Aquat. Sci. 50, 2305-2314.

Mills, E.L., Rosenberg, G., Spidle, A.P., Ludyanskiy, M., Pligin, Y., May, B., 1996. A review of the biology and ecology of the quagga mussel (Dreissena bugensis), a second species of freshwater dreissenid introduced to North America. Amer. Zool. 36, 271-286.

Mills, E.L., Chrisman, J.R., Baldwin, B.B., Owens, R.W., O'Gorman, R., Howell, T. Roseman, E.F., Raths, M.K., 1999. Changes in the dreissenid community in the lower Great Lakes with emphasis on southern Lake Ontario. J. Great Lakes Res. 25 187-197.

Mohr, L.C., Nalepa, T.F., 2005. Proceedings of a Workshop on the Dynamics of the Lake Whitefish (Coregonus clupeaformis) and the Amphipod Diporeia spp. in the Great Lakes. Great Lakes Fishery Commission Technical Report, 69. Grat Lake Fishery Commission, Ann Arbor, MI.

Mozley, S.C., Winnell, M.H., 1975. Macrozoobenthic species assemblages of southeastern Lake Michigan. U. S. A. Verh. Internat. Verein. Limnol. 19, 922-931.

Nalepa, T.F., 1989. Estimates of macroinvertebrate biomass in Lake Michigan. J. Great Lakes Res. 15, 437-443.

Nalepa, T.F., Fahnenstiel, G.L., 1995. Dreissena polymorpha in the Saginaw Bay Lake Huron ecosystem: overview and perspective. J. Great Lakes Res. 21, 411-416.

Nalepa, T.F., Cavaletto, J.F., Ford, M., Gordon, W.M., Wimmer, M., 1993. Seasonal and annual variation in weight and biochemical content of the zebra mussel, Dreissena polymorpha, in Lake St. Clair. J. Great Lakes Res 19, 541-552.

Nalepa, T.F., Wojcik, J.A., Fanslow, D.L., Lang, G.A., 1995. Initial colonization of the zebra mussel (Dreissena polymorpha) in Saginaw Bay, Lake Huron: population recruitment, density and size structure. J. Great Lakes Res. 21, 417-434.

Nalepa, T.F., Hartson, D.J., Gostenik, G.W., Fanslow, D.L., Lang, G.A., 1996. Changes in the freshwater mussel community in Lake St. Clair: from Unionidae to Dreissena polymorpha in eight years. J. Great Lakes Res. 22, 354-369.

Nalepa, T.F., Hartson, D.J., Fanslow, D.L., Lang, G.A., Lozano, S.J., 1998. Declines in benthic macroinvertebrate populations in southern Lake Michigan, 1980-1993. Can. J. Fish. Aquat. Sci. 55, 2402-2413.

Nalepa, T.F., Schloesser, D.W., Pothoven, S.A., Hondorp, D.W., Fanslow, D.L., Tuchman, M.L., Fleischer, G.W., 2001. First finding of the amphipod Echinogammarus ischnus and the mussel Driessena bugensis in Lake Michigan. J. Great Lakes Res. 27, 384-391.

Nalepa, T.F., Fanslow, D.L., Lansing, M.B., Lang, G.A., 2003. Trends in the benthic macroinvertebrate community of Saginaw Bay, Lake Huron, 1987 to 1996 responses to phosphorus abatement and the zebra mussel, Dreissena polymorpha. J. Great Lakes Res. 29, 14-33.

Nalepa, T.F., Fanslow, D.L., Lang, G.A., 2009. Transformation of the offshore benthic community in Lake Michigan: recent shift from the native amphipod Diporeia spp. to the invasive mussel Dreissena rostriformis bugensis. Freshw. Biol. 54, 466-479.

Nichols, S.J., 1993. Spawning of zebra mussels (Dreissena polymorpha) and rearing of veligers under laboratory conditions. In: Nalepa, T.F., Schloesser, D.W. (Eds.), Zebra Mussels: Biology, Impacts, and Control. CRC Press, Boca Raton, FL, pp. 315-329. 
Nichols, S.J., 1996. Variations in the reproductive cycle of Dreissena polymorpha in Europe, Russia, and North America. Amer. Zool. 36, 311-315.

Packard, T.T., 1971. The measurement of respiratory electron-transport activity in marine phytoplankton. J. Mar. Res. 29, 235-244.

Packard, T.T., Healy, M.L., Richards, F.A., 1971. Vertical distribution of the activity of the respiratory electron transport system in marine plankton. Limnol. Oceanogr. 16, 60-70.

Patterson, M.W.R., Ciborowski, J.J.H., Barton, D.R., 2005. The distribution and abundance of Dreissena species (Dreissenidae) in Lake Erie, 2002. J. Great Lakes Res. 31 (Suppl. 2), 223-237.

Pothoven, S.A., Nalepa, T.F., 2006. Feeding ecology of lake whitefish in Lake Huron. J. Great Lakes Res. 32, 489-501.

Ram, J.L., Nichols, S.J., 1993. Chemical regulation of spawning in the zebra mussel (Dreissena polymorpha). In: Nalepa, T.F., Schlowsser, D.W. (Eds.), Zebra Mussels: Biology, Impacts, and Control. CRC Press, Boca Raton, FL, pp. 315-329.

Rheault, R.B., Rice, M.A., 1996. Food-limited growth and condition index in the eastern oyster, Crassostrea virginica (Gmelin, 1791), and the bay scallop, Agropecten irradians irradians (Lamarck 1819). J. Shellfish Res. 15, 271-283.

Roe, S.L., MacIsaac, H.J., 1997. Deepwater population structure and reproductive state of quagga mussels (Dreissena bugensis) in Lake Erie. Can. J. Fish. Aquat. Sci. 54, 2428-2433.

Roehrig, K.L., Allred, J.B., 1974. Direct enzymatic procedure for the determination of liver glycogen. Anal. Biochem. 58, 414-421.

Schlechtriem, C., Johannsson, O.E., Bowen, K.L., Smith, R.W., Arts, M.T., 2008. Effect of fasting under different temperature conditions on nucleic acid rations in the opossum shrimp Mysis relicta: a calibration approach. J. Great Lakes Res. 34, 461-471.

Spidle, A.P., Marsden, J.E., May, B., 1994. Identification of the Great Lakes quagga mussel as Dreissena bugensis from the Dnieper River, Ukraine, on the basis of allozyme variation. Can. J. Fish. Aquat. Sci. 51, 1485-1489.

Sprung, M., 1987. Ecological requirements of developing Dreissena polymorpha eggs. Arch. Hydrobiol. Suppl. 79, 69-86.

Sprung, M., 1989. Field and laboratory observation of Dreissena polymorpha larvae: abundance, growth, mortality and food demands. Arch. Hydrobiol. 115, 537-561.

Sprung, M., 1995. Physiological energetics of the zebra mussel Dreissena polymorpha in lakes: I. Growth and reproductive effort. Hydrobiologia 304, 117-132.
Sprung, M., Borcherding, J., 1991. Physiological and morphometric changes in Dreissena polymorpha (Mollusca:Bivalvia) during a starvation period. Malacologia 33, 179-191.

Stoeckmann, A., 2003. Physiological energetics of Lake Erie dreissenid mussels: a basis for the displacement of Dreissena polymorpha by Dreissena bugensis. Can. J. Fish. Aquat. Sci. 60, 126-134

Van Handle, E., 1985. Rapid determination of total lipids in mosquitoes. J. Am. Mosq. Control. Assoc. 1, 302-304.

Vanderploeg, H.A., Nalepa, T.F., Jude, D.J., Mills, E.L., Holeck, K.T., Liebig, J.R., Grigorovich, I.A., Ojaveer, H., 2002. Dispersal and emerging ecological impacts of Ponto-Caspian species in the Laurentian Great Lakes. Can. J. Aquat. Sci. 59, 1209-1228.

Vanderploeg, H.A., Johengen, T.H., Liebig, J.R., 2009. Feedback between zebra mussel selective feeding and algal composition affects mussel condition: did the regime changer pay a price for its success? Freshw. Biol. 54, 47-63.

Vanderploeg H.A., Liebig J.R. Nalepa, T.F, Fahnenstiel, G.L, Pothoven, S.A, 2010. Dreissena and the disappearance of the spring phytoplankton bloom in Lake Michigan. J. Great Lakes Res. 36 (Supplement 3), 50-59.

Wacker, A., von Elert, E., 2003. Settlement pattern of the zebra mussel, Dreissena polymorpha, as a function of depth in Lake Constance. Arch. Hydrobiol. 153, 289-301.

Wacker, A., von Elert, E., 2008. Body size and food thresholds for zero growth in Dreissena polymorpha: a mechanism underlying intraspecific competition. Freshw. Biol. 53, 2356-2363.

Walz, N., 1978a. The energy balance of the freshwater mussel Dreissena polymorpha Pallas in laboratory experiments and Lake Constance: III. Growth under standard conditions. Arch. Hydrobiol. 55, 121-144.

Walz, N., 1978b. The energy balance of the freshwater mussel Dreissena polymorpha Pallas in laboratory experiments and Lake Constance: III. Growth in Lake Constance. Arch. Hydrobiol. Suppl. 55, 142-156.

Watkins, J.M., Dermott, R., Lozano, S.J., Mills, E.L., Rudstram, L.G., Scharold, J.V., 2007. Evidence for remote effects of dreissenid mussels on the amphipod Diporeia: analysis of the Lake Ontario benthic surveys, 1972-2003. J. Great Lakes Res. 33, 642-657.

Wilson, K.A., Howell, E.T., Jackson, D.A., 2006. Replacement of zebra mussels by quagga mussels in the Canadian nearshore of Lake Ontario: the importance of substrate, round goby abundance, and upwelling frequency. J. Great Lakes Res. 32, 11-28. 